\title{
懸濁物質による砂充塡層内の目づまりと 再揚水による透水係数の回復について
}

上田年比古* 神野 健二* 安田 裕* 重藤 恵昭**

\section{Analyses of Clogging Phenomena in Porous Media and the Recovery of Permeability by Back-pumping}

Toshihiko UEDA*, Kenji JINNO*, Hiroshi YASUDA* and Yoshiaki SHIGETOU**

\begin{abstract}
One of the difficult problems in planning an artificial groundwater recharge is the prediction of cloggings in aquifers. In the present study, the mechanism of the clogging caused by suspended solids in recharge water and the effect of back-pumping for recovery permeability are discussed through theoretical and experimental analyses.

The following results are obtained:

(1) the clogging phenomenon can be simulated by the filtration equations;

(2) the relation between the amount of clogging solids and the reduced permeability can be expressed by the Kozeny-Stein equation; and

(3) by assuming that the flow through the capillary tube, the quantitative estimation of the effect of back-pumping can be realized: the effect depends on the magnitude of the shear stress exerted by the flow on the sand grains.

\section{I まえがき}

地下水は古来より安定した良質の水資源として利 用されてきたが，近年地下水の過剩揚水が原因で地 般沈下や井戸枯れあるいは塩水侵入など，種々の地 下水障害が各地で発生している。このような障害は,

* 九州大学工学部 Faculty of Engineering, Kyusyu University

** 九州大学大学院工学破究科 Graduate Student, Kyusyu University

水資源として過剩揚水されること以外にも，大規模 な建設工事の際の地下水位低下によっても引き起さ れることがしばしば報告されている。

さて，以上のよらに枯渴しつつある地下水の補強 策として最近，地表の余䣋水を人工的に地下に注入 する，いわゆる地下水の人工湴巻が各地で恰討され つつあるが，人工涵養のメカニズムの理解は上述の 理由により水資源関係者のみならず建設工事関俰者 にも必要なことと考えられる。
\end{abstract}


人工涵養を行ら上で，最す困難な問題の一つとし て帯水層の目づまりがあげられている”。水資源の 有効利用の立場あるいは経済的な理由から，清浄な 水の注入よりは洪水時の河川水や下水処理水などを 注入するほらが効率的と考えられるが，この場合， 目づまりが問題となる。注入井中の㲘濁粒子が原因 で発生する目つまり現象は，注入井や浸透池の側面 扣よび底面の浸透層に愳濁粒子が抑留され間隙が狭 くなり，透水性が低下し注入流量が減少する現象と 考えられる。

注入井による地下水人工涵養時の目づまり現象に 関する研究として Rebhum, M \& Schwasz, J (1968 年)2）の㬰験的研究，あるいは目つうまり現象を愁濁粒 子のろ過現象と考え，これにろ過理論を適用した北 川・石崎 $(1980 \text { 年 })^{3)}$ の研究などがあるが，注入初期 の時点の解析であり，目つうまりが十分に進行した状 態までの解析はなされていないようである。さて， このよらな懸濁粒子による目づまり現象は, 主に注 入側にきわめて近い浸透層で発生する現象であるが， 注入井戸を用いた人工涵羔では，目づまりを起した 帯水層から再び地下水を揚水することによって䋰濁 粒子を吪離させて吸い出し，目づまりを除去するい わゆる再揚水対策が取られることがある。しかし再 揚水の効果については定量的な検討 ${ }^{4}$ はあまり加え られていないようである。

本報に拀いては地下水の人工涵養計画にあたって の必要な基礎的知見を得るため，人工涵亘時の䋰濁 物質による目づまり過程のメカニズム解析と，再揚 水効果について数值シミュレーションによる定量的 な検討を行ったすのである。特に，目つうり過程に 対してろ過方程式を応用し，また再揚水による抑留 物質の制離は，浸透層の空隙を細管でモデル化し， この細管に作用するせん断応力によるすのとして解 析を行っている。

\section{II 基 碳 式}

\section{1 流れの基礎式}

実際の人工涵養は注入井戸や浸透池などを用いて 行われるが，本報では 因-1 に示すよらな一次元一 様流の浸透層についての室内実験拉よびこれに対す

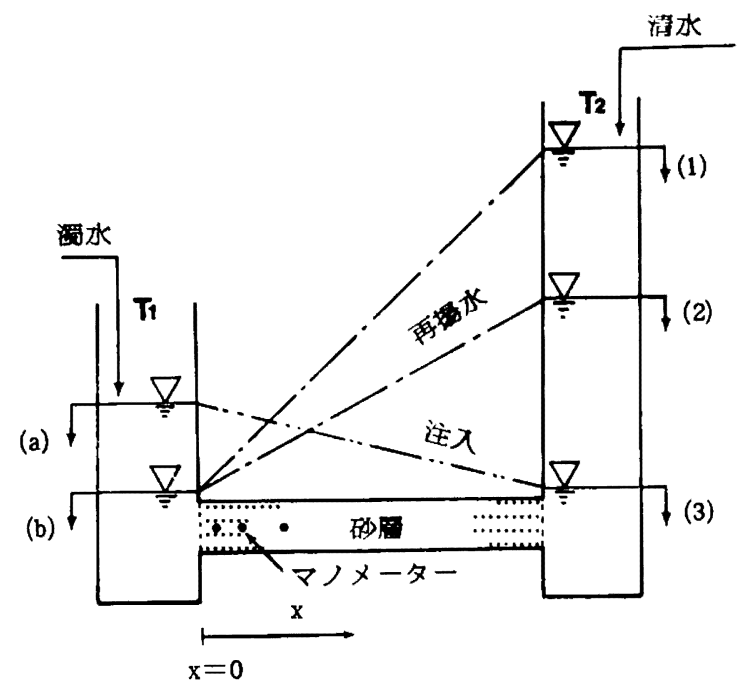

图-1 実駼装置

Fig. 1 Experimental apparatus

る数值シミュレーションを行う（なお，注入井戸を 用いる場合には, 方程式を円柱座標表示し以下に示 す方法と同様の展開を行ら)。

連続の式は, 空隙率の時間変化が小さいとして, これを無視すれば

$$
\frac{\partial u}{\partial x}=0
$$

運動方程式は，ダルシーの法則が成り立つとして

$$
u=-k \cdot \frac{\partial \phi}{\partial x}
$$

ここに, $u$; 断面平均流速 $(\mathrm{cm} / \mathrm{sec}), k$; 透水係数 $(\mathrm{cm} / \mathrm{sec}), \phi$; 水頭 $(\mathrm{cm}), x$; 座標 $(\mathrm{cm})$, 注入の 方向を正の向きにとる。な拉，再揚水時においても ダルシーの法則が成り立つものと仮定する。

2 目つまりを表す式

目づりり現象を表現するために，次のよらな照濁 物質保存の方程式(3)と㲘濁物質の抑留式(4)を用いる。 


$$
\begin{aligned}
& \frac{\partial C}{\partial t}+\frac{u}{\varepsilon} \cdot \frac{\partial C}{\partial x}+\frac{\sigma_{8}\left(1-\varepsilon_{0}\right)}{\varepsilon} \frac{\partial q_{s}}{\partial t}=0 \\
& \frac{\sigma_{8}\left(1-\varepsilon_{0}\right)}{\varepsilon} \cdot \frac{\partial q_{s}}{\partial t}=\beta_{1}\left(1-\beta_{2} q_{s}\right) C \\
& -\beta_{3} f(\tau) q_{8}
\end{aligned}
$$

ここで,

$$
\begin{aligned}
& f(\tau)=\frac{\left(\tau-\tau_{c}\right) U n\left(\tau-\tau_{c}\right)}{\tau} \\
& \tau=\frac{\rho \cdot g r}{2} \frac{\partial \phi}{\partial x} r^{\prime} \\
& r^{\prime}=\left\{1-\frac{\sigma_{s} \cdot(1-\varepsilon) q_{s}}{\varepsilon_{0} \sigma_{h}\left(1-f_{\sigma}\right)}\right\}^{1 / 2} r_{0}
\end{aligned}
$$

ここに, $C$; 空隌水中の愁濁物質濃度 $\left(\mathrm{g} / \mathrm{cm}^{3}\right), \varepsilon$; 浸 透層空隙率, $\varepsilon_{0}$; 初期空隙率, $\sigma_{8}$; 漫透層構成材料 (以下ろ材といら) の単位体積重量 $\left(\mathrm{g} / \mathrm{cm}^{3}\right), \sigma_{h}$; 懸 濁物質の単位体積重量 $\left(\mathrm{g} / \mathrm{cm}^{3}\right), q_{s}$; 万材単位体積 重量あたりの愁濁物質抑留重量(無次元量), $\tau$; せん 断応力 $\left(\mathrm{dyn} / \mathrm{cm}^{2}\right), \tau_{c}$; 限界せん断応力 $\left(\mathrm{dyn} / \mathrm{cm}^{2}\right)$, $\rho$; 水の密度 $\left(\mathrm{g} / \mathrm{cm}^{3}\right), g r$; 重力の加速度 $\left(\mathrm{cm} / \mathrm{sec}^{2}\right)$, $U n(\tau)$; 単位ステップ関数 $(\tau \geqq 0 て ゙ 1, \tau<0 て ゙ 0), r^{\prime}$;

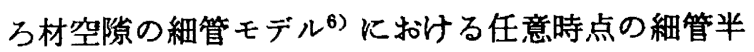
径 $(\mathrm{cm}), \mathrm{r}_{0}$; 細管モデルの初期細管半径 $(\mathrm{cm}), \beta_{1}$, $\beta_{2}, \beta_{3}$ : 実験定数, $t$; 時間 $(\mathrm{sec}), f_{\sigma}$; 二次空吵率(慗 濁物質の抑留状態での空隙率, 詳細は II-3, II-4)。

式(3)拉よび式(4)の右辺の第 2 項を除いた式はろ 過江関する基礎方程式である（参考文献 5 ))。また 式 (4) の右辺第 2 項は本報で新しく導入したせん

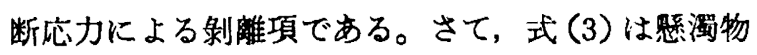
質を含む流体の単位体積, 単位時間の愁濁物質の連 続の方程式で, 左辺の第 1 項は単位時間あたりの流 体の単位体積内の愁濁物質の增加量, 第 2 項は単位 時間に流体の単位体積から出ていく愁濁物質量，第 3 項は単位時間に単位体積の流体から分離して, ろ 材に抑留する愁濁物質量である。なお，第 3 項の $\partial \mathrm{q}_{s} / \partial \mathrm{t}$ にかかる係数はろ材の単位体積重量あたり の抑留最 q。を流体の単位体積あたりの抑留量にす るための係数である。なお，式（3）では一般のろ過 方程式と同様に扗散項を除いている。これは，ここ
で取り扱っている現象はろ過と同様に計算值の浱度 が主に，ろ材への㧕留によって変化する場合である ことから，一般に小さいと考えたからである（参考 文献(3))。なお, 式 (3) の $\partial C / \partial t$ あまた, 移流項 $u / \varepsilon \cdot \partial C / \partial x$ に比ぺてろ過では一般に小さいと考え られているが (参考文献5)), ここでは再揚水時の 濃度の急䑤な変化を考えてこの項は残して計算を行 っている。

次に, 式 (4) は愁濁物質を含む流体の単位時間, 単位体積の䋰濁物質の抑留および吪離の量をきめる 関係式で，左辺は式(3)の右辺第 3 項と同じである。 次に, 式 (4) の右辺第 1 項は愁濁物質の抑留量を 示すもので, 抑留はその時点での㦟渴物質の濃度に 比例することを示している。この比例定数はろ過に 扣ける阻止率 $\lambda$ で, Ives, K. J. (1975) ${ }^{7)}$ は, 次式 を提案している。

$$
\lambda=\beta_{1}\left(1-\beta_{2} q_{s}\right)^{\wedge} \cdot\left(1+\beta_{2}^{\prime} q_{s}\right)^{\mathbf{B}}
$$

ここに， $\lambda, \beta_{1}, R_{2}, R_{2}{ }^{\prime}, A, B$ は定数である。この式 は，図-2に示すよ5に，阻止率入が愁濁物質の抑留 によって変化することを表している。すなわち，俰 数 $\beta_{1}$ は抑留率が愁濁粒子湿度に比例して增加する 効果を表わし， $\beta_{2}$ が含まれている項は抑留量が增加 すると, 空隙内の流速が增大して舅濁粒子が付着し にくくなり，抑留率が隇少する効果を表わし，また， $R_{2}{ }^{\prime}$ を含む項 $\left(1+R_{2}{ }^{\prime} q_{s}\right)$ は $B_{2}$ の項とは逆に抑留量

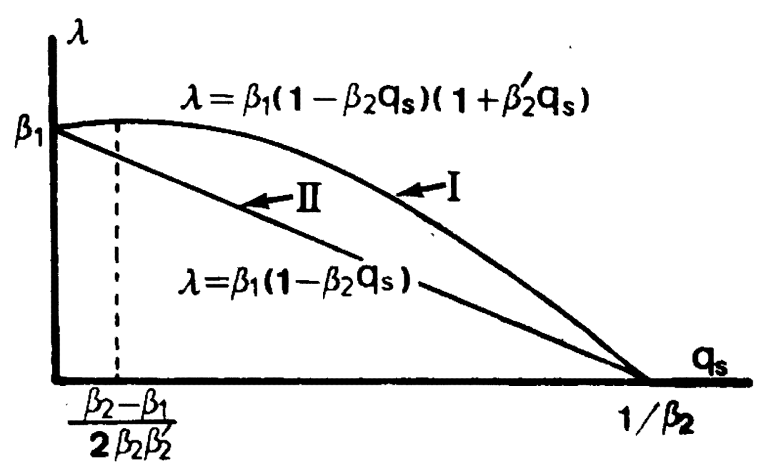

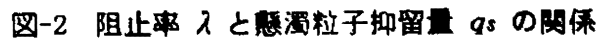

Fig. 2 Relationship between coefficient of filtration $\lambda$ and captured clogging material $q s$ 
が增加すると空隚が狭くなり抑留率が增加する奻果 を表している。これらの定数は賏濁粒子と流体の物 理化学的特性, 万材の大ささや形状，扰よび浸透層 の特性などよって変化する量と考えられ，現時点 においては一般的な決定法を見出すことは極めて困 難である。なお，入は図-2のI線のよらに注入開始 時の $\lambda\left\{q_{s}=0\right.$ の時の $\left.\lambda\left(=\beta_{1}\right)\right\}$ から, 初期の段階で,

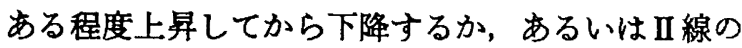
ようにはじめから下降していくかは問題となるとこ ろであるが，現在まで，これについての定説はない。 $\left(1+R_{2}{ }^{\prime} q_{s}\right)$ の項すなわち $B_{2}^{\prime}$ が大きくなるにつれ 入 が上に凸の傾向が強くなり， $\beta_{2}{ }^{\prime}$ が少さくなると II 楾のよらに入の上昇の傾向がなくなる。な特, 入が I 線のように初期の段階で上界する時は，流量の初 期の段階で減少が急激になるるのと考えられる。本 報では流量 $Q$ の実測值は後述の図-13（a)〜(e)に 見られるように，初期の段階で $Q$ の減少が特に急 になっているとは見られないので, ここでは $B_{2}{ }^{\prime}$ の 項は除いて，次の式(9)を用いることにする。

$$
\lambda=\beta_{1}\left(1-\beta_{2} q_{s}\right)
$$

なお，図-2の II 線は式(9)を表わしている。

次に式（4）の右辺第 2 項は浸透層に抑留された㴽 濁粒子が再揚水時に剥離される量を表している。本 報では再揚水効果を評価するために，浸透層を図-3 に示すよらな細管でモデル化しこの細管壁上に作用 するせん断応力の大きさを見積るることを提案して いる。均一粒径のろ材からなる浸透層に打いては， 粒径のほぼ 5 分の 1 程度がモデル化した細管の半径

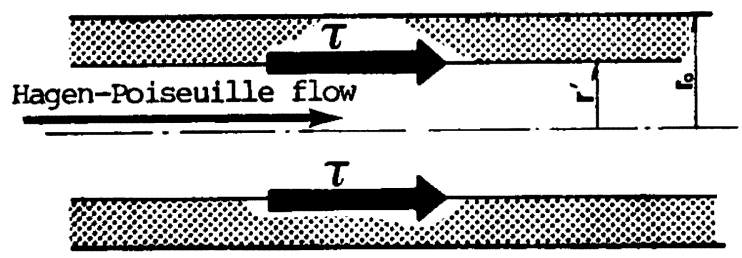

図-3 細管モデルにおけるせん断応力

Fig. 3 Shear stress on inner surface of capillary tube
に相当するといわれている8)。いま慗濁物質が抑留 されていない初期状態の，この細管半径を $r_{0}$ とし よう。㲘濁粒子が抑留 (抑留量 $\mathrm{q}_{8}$ ) された時の細管 半径を $r^{\prime}$ とし， $q_{8}$ が一様の厚さで細管半径に付着 するすのとすれば式(7)となる。

次に，再揚水時においても流れが層流状態である とし，細管内では Hagen-Poiseulle の流れとなって いると考えれば，細管壁面上に作用するせん断応力 は式(6)となる。

（6）式から判るようにせん断応力の変化は水頭勾 配の場所的, 時間的变化と細管モデルの半径の变化 によって表される。

燱濁粒子がせん断応力によって剥離されるために はある一定値以上のせん断応力が作用することが必 要であろう。いまこの限界のせん断応力を $\tau_{c}$ とし， てがで超えるときに剩離が生じると仮定する。

剥離量はこがてよりる大きい汪ど增加するとし て式(5)に示すような関数を考光, 剝離量はこの $\mathrm{f}(\tau)$ に比例するとする。

また剝離量は抑留量: $q_{8}$ が大きいほど多くなると 考える。

以上のように考えて，単位時間に，流体の単位体 積あたりの剥離量を表わす式として，次式を与える。

$$
j=\frac{\beta_{3} \varepsilon f(\tau) q_{s}}{\sigma_{s}\left(1-\varepsilon_{0}\right)}
$$

これが，式(4)の右辺第 2 項である。

3 空隙率と照濁粒子抑留量との関係式

䅗濁粒子の抑留により浸透層の空隙率が減少する が, 任意時間および任意場所に括ける空吵率 $\varepsilon(x, t)$ は次のよらになる。

いま，fo を抑留懸渴粒子間に生じている空隙の 空吵率(これを2次空吵率といら) 層単位体積当たりの抑留㲘渭粒子の体積とすると, ろ材単位体積重量当たりの抑留量 (重是) $q_{s}$ との関 係は 


$$
v=\frac{\sigma_{s}(1-\varepsilon) q_{s}}{\sigma_{h}(1-f \sigma)}
$$

を考えなければならない。従って

$$
\varepsilon(x, t)=\varepsilon_{0}-v=\varepsilon_{0}-\frac{\sigma_{s}\left(1-\varepsilon_{0}\right) g_{s}}{\sigma_{h}(1-f \sigma)}
$$

となる。

4 透水係数之愁濯粒子抑留量との関係式

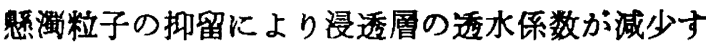
るが抑留量と透水係数との関係式にはKozeny-Stein 式があり，以下のよ5にして導かれる。

透水係数に関する Kozeny の式は周知のように

$$
k_{0}=\frac{\gamma \cdot g r \cdot d^{2} \cdot \varepsilon_{0}}{v\left(1-\varepsilon_{0}\right)^{2}}
$$

ここに， $r$; 係数, $d$; 万材粒径， $v$; 浸透層単位体 積中の抑留量（体積）で表されるが，Stein（参考文 献9)）は懸濁粒子が抑留されたとさにも次のような 仮定が成り立つとしている。すなわち，

(1)慜濁粒子はろ材表面に均等に抑留される。(2)称 濁粒子が抑留されてもろ材の形状は変らない。

緊濁粒子が抑留され，ろ材径が $\Delta d$ だけ增加した とすると，浸透層単位体積中の抑留量（体積）vは

$$
v=\frac{\left(1-\varepsilon_{0}\right)\left\{\alpha(d+\Delta d)^{3}-\alpha_{0} d^{3}\right\}}{\alpha_{0} d^{3}}
$$

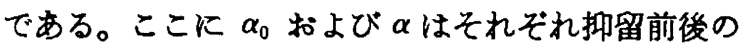
ろ材の形状係数である。いまの場合，仮定(2)により $\alpha=\alpha_{0}$ である。また $(\Delta d)^{3}$ の項を小さいとして無 視すると式(13)より

$$
\Delta d=d\left(\frac{v}{3\left(1-\varepsilon_{0}\right)}+\frac{1}{4}\right)^{1 / 2}-\frac{1}{2}
$$

このとき Kozeny 式は

$$
k=\frac{r \cdot g r\left(\varepsilon_{0}-v\right)^{3}(d+\Delta d)^{2}}{v\left(1-\varepsilon_{0}+v\right)^{2}}
$$

式(12)と式(15)との比をとると

$$
\frac{k}{k_{0}}=\frac{\left(\varepsilon_{0}-v\right)^{3}\left(1-\varepsilon_{0}\right)^{2}}{\varepsilon_{0}^{3}\left(1-\varepsilon_{0}+v\right)^{2}}\left\{\left(\frac{v}{3\left(1-\varepsilon_{0}\right)}+\frac{1}{4}\right)^{1 / 2}\right.
$$

$$
\left.+\frac{3\left(1-\varepsilon_{0}\right)}{v}+\frac{1}{2}\right\}
$$

となる。式（16）のvに式（12）を用いれば，次の Kozeny-Stein 式得る。

$$
\begin{aligned}
& \frac{k}{k_{0}}=\frac{\left[\varepsilon_{0}-\left(1-\varepsilon_{0}\right) \sigma_{s} \cdot q_{s} /\left\{\sigma_{h}(1-f \sigma)\right\}\right]^{3}}{\varepsilon_{0}^{3}\left[1+\sigma_{s} q_{s} /\left\{\sigma_{s}(1-f \sigma)\right\}\right]^{2}} \\
& \left\{\left(\frac{\sigma_{s} q_{s}}{3 \sigma_{s}(1-f \sigma)}+\frac{1}{4}\right)^{1 / 2}\right. \\
& \left.+\frac{\sigma_{s} q_{s}}{3 \sigma_{h}(1-f \sigma)}+\frac{1}{2}\right\}
\end{aligned}
$$

\section{III 数值暗算について}

\section{1 懸濁物質の数値計算}

前節で示した方程式のらちで，数值計算の安定性 上もっとも注意すべき式は㲘濁物質の連続方程式と 考えられ，式 (3) の左辺第 2 項の移流項は流速が大 きい時に大きな離散化誤差が発生することが知られ ている。特に目づまり過程に执いて十分に抑留が進 行し, 式（3）の左辺第 3 項の抑留項が小さくなった 段階では式（3）は実質的には 1 次元の波動方程式と なり安定性が低下することが考えられる。著者らは このよらな輸送過程にも十分な精度を持つ数値計算 手法について検討し以下に示すよ5な粒子移動法 ${ }^{10}$ を提案している。

この方法は式(3)で,

$$
\frac{\partial C}{\partial t}+\frac{u}{\varepsilon} \cdot \frac{\partial C}{\partial x}=\frac{d C}{d t}
$$

とおく。すなわち $u / \varepsilon$ の速度を持つ特性曲線上で は式(3)は

$$
\frac{d C}{d t}=-\frac{\sigma_{s}\left(1-\varepsilon_{0}\right)}{\varepsilon_{0}} \cdot \frac{\partial q_{s}}{\partial t}
$$

と書くことができる。粒子移動法では(3)'のように 見掛け上移流項 $u / \varepsilon \cdot \partial C / \partial x$ を消去した式について， 計算領域内に当該の港度を持つ仮想の流体粒子を目 置し、これを粒子位置に批ける流速で移動させなが ら，式(3)' を数值解析するすので，移流項て乣生す 
る数値計算上の誤差を除いた計算法である。ここで は、計算のアルゴリズムについては述べないが，詳 しくは文献 10）を参考にされたい。

いま，粒子移動法の算定精度を確かめるために次 式のような移流分散方程式に抑留項 $C C$ が加わった 方程式の数値計算を考学る。

$$
\frac{\partial C}{\partial t}+u \frac{\partial C}{\partial x}=D \frac{\partial^{2} C}{\partial x^{2}}-\lambda C
$$

\section{境界, 初期条件}

$$
C(0, t)=C_{0}, C(\infty, t)=0, \quad C(x, 0)=0
$$

これを粒子移動法では式(19)の条件のもとに

$$
\frac{d C}{d t}=D \frac{\partial^{2} C}{\partial x^{2}}-\lambda C
$$

によって数值計算することになる。ここでは $u=$ $0.08 \mathrm{~cm} / \mathrm{sec}$, 払散係数 $D=0.08 \mathrm{~cm}^{2} / \mathrm{sec}$, 阻止率 $\lambda$ $=0.0008 / \mathrm{sec}$ とし, 数值計算では $\Delta x=3.0 \mathrm{~cm}$, $\Delta t=20.0 \sec$ にとる。

なお，式(18)，（19)の解析解は

$$
\begin{aligned}
C= & \frac{1}{2} \cdot C_{0} \exp \left(\frac{u x}{2 D}\right)\left[\operatorname { e x p } \left\{-x\left(\frac{u^{2}}{4 D^{2}}\right.\right.\right. \\
+ & \left.\left.\frac{\lambda}{D}\right)^{1 / 2}\right\} \operatorname{erfc}\left\{\frac{x-\left(u^{2}+4 \lambda D\right)^{1 / 2}}{2(D t)^{1 / 2}} t\right\} \\
+ & \exp \left[x\left(\frac{u^{2}}{D^{2}}+\frac{\lambda}{D}\right)^{1 / 2}\right] \operatorname{erfc} \\
& \left.\left\{\frac{x+\left(u^{2}+4 \lambda D\right)^{1 / 2}}{2(D t)^{1 / 2}} t\right\}\right]
\end{aligned}
$$

式 (18) の explicit 差分法による数值解, 式(20)

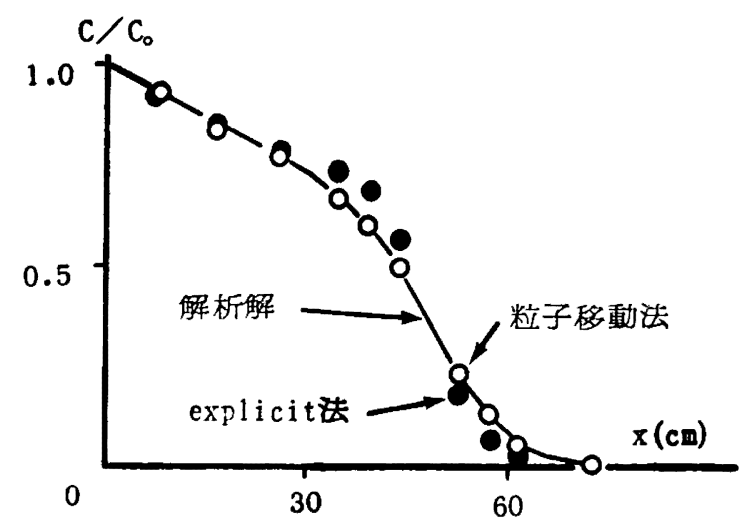

图-4 数值計算の精度（式(20)）

Fig. 4 Accuracy of numerical calculation(eq. (20))
についての粒子移動法による数値解扰よび式(21)に よる解析解を図-4に示している。四-4は $t=620 \mathrm{sec}$ のとさの $\mathrm{x}$ 軸上の濁度分布を示している。同図よ り,このような計算条件下では粒子移動法が十分の 精度を持つ計算法と考えられ, 従って式 (3) の数值 計算にはこの粒子移動法を用いて行った。

\section{2 数值シミュレーション}

本報では現象の全過程をシミュレートし実測值と の適合度を見て，与えられた式の妥当性，現象のと らえかたの良否を検討することにしている。シミュ レーションは式(1), (2), (3), (4), (5), (6), (7), (11) 扣よび(17)から末知数 $\phi, k, \varepsilon, C, q, u, \tau, f(\tau), \mathrm{r}^{\prime}$ が時間と場所の関数として同時に算出されていく。 またここから $Q=A u$ ( $A$ は浸透層断面積) が得 られる。この場合, $\sigma_{s}=\sigma_{h}=2.65 \mathrm{~g} / \mathrm{cm}^{3}, r_{0}=0.01 \mathrm{~cm}$ とし、また $f \sigma=0.90$ (図-11より得られた値)， $\beta_{2}=$ $20.0\{\mathrm{~V}-2$ の) 参照 $\}, \beta_{3}=0.4\left(\mathrm{~g} / \mathrm{cm}^{3} \cdot \mathrm{sec}\right)\{\mathrm{V}-2$-2 4$)$ 参照 $\}$ 用い, $\varepsilon_{0}$, 注入濁度 $\left(C_{i n}\right), k_{0}$ は表-1の値を 与えた。つぎに， $\beta_{1} 、 \tau_{c}$ はV -2の 2) および5) で述 べるように, 種々の值を与えてシミュレーションを 行い妥当な值を求めた。すなわち, 本報では， $\beta_{1}$, זcの妥当な值を求めるためにシミュレーションを 行っている。なお，式（3）には前述の粒子移動法を 用いている。また, てく祙のときは剝離を生じない $\{f(\tau)=0$ となる $\}$ こから, 注入実験のシミュレー ションのときは式 (4) の右辺第 2 項は除いて計算を 行っている。

以後, シミュレーションとあるのは上述の計算を 指すものである。

\section{N 実 験}

\section{1 実験装置の概要}

困-1に示す装置を用いて愁濁水の注入時の目づま りおよび再揚水の效果について奖験を行った。装疽 には同一規格の 2 本の浸透㬝 (浸透䅉の長さ $40 \mathrm{~cm}$, 正方形断面 $6 \mathrm{~cm} \times 6 \mathrm{~cm}$, , 断面積 $36.0 \mathrm{~cm}^{2}$ ) がッ 
ドタンク $\mathrm{T}_{1}, \mathrm{~T}_{2}$ に平行して取り付けられている。

これは 2 本の漫透層を同一条件下で実験を行らため

であり，両者の初期透水係数も十分に等しくなるよ

らにろ材を充埧している。注入実験はへッドタンク

$\mathrm{T}_{1}$ の水位を(a)に, $\mathrm{T}_{2}$ の水位を(3)にし，再揚水実験

は $\mathrm{T}_{1}$ の水位を(b)に, $\mathrm{T}_{2}$ の水位を (1) または(2)

に上昇させて行っている。実験では同時に 2 本の浸

透層を使って注入するが，再揚水効果を調べる時に

は片方の浸透層（B層とする）のみを再揚水し，再

揚水しない方の浸透層（A層とする）と比較する。

また, 注入実験終了後, $\mathrm{A}$ 層の上蓋をはずし, 抑留

量 $q_{s}$ を測定し，これを $\mathrm{B}$ 層の再揚水のシミュレー

ションの $q_{8}$ に関する初期条件として与兄ている。

さらに，再揚水実験釉了後 B 㬝の上蓋をはずし，抑

留量 $q_{3}$ を測定する。実験中の水頭変化を調べるた めにマノメータを取り付けているが，目づまりが大 きい $T_{1}$ 側には密に配置している。注入㦟濁水漒度 は北斗理研会社製の澌度計（MA500s）で実測して
いる。

\section{2 実験条件}

本報では，表-1のように実験を12回行っている。 表中で目づまり度は，注入実験最終状態での浸透層 全体の平均の透水係数 $k$ と初期（注入実験開始時） 平均透水係数 $k_{0}$ を用いて $\left(k_{0}-k\right) / k_{0}$ で表わす。ま た，再揚水後の目つまり度も再揚水実験終了後の浸 透阄全体の平均透水係数 $k^{\prime}$ と初期（注入実験開始 時）平均透水係数 $k_{0}$ を用いて $\left(k_{0}-k^{\prime}\right) / k_{0}$ とする。 実験には，ろ材として $0.5 \mathrm{~mm}$ 径の砂を用い。照濁 粒子としては図-5に示す粒径の分布を持つ博多湾の 粘土質シルトを用いている。

\section{$\mathrm{V}$ 実験結果および物理定数についての考察}

\section{1 実験結果についての考察}

1）注入流量の変化

楻濁水注入時の浸透層の流量は図-6（a）のよらに 変化し, 目づまりの進行とともに減少してゆく。実

表-1 実 験 条 件

Tab. 1 Experiment condition

\begin{tabular}{|c|c|c|c|c|c|c|c|c|}
\hline 央験番号 & $\begin{array}{c}\text { 初期 透 } \\
\text { 水係数 } \\
k_{0} \\
\mathrm{~cm} / \mathrm{s}\end{array}$ & $\begin{array}{c}\text { 初 期 } \\
\text { 腺 } \\
\varepsilon_{0} \\
\varepsilon_{0}\end{array}$ & $\begin{array}{c}\text { 注入濁度 } \\
\qquad \begin{array}{c}C_{i n} \\
\mathrm{mg} / l\end{array}\end{array}$ & $\begin{array}{l}\text { 注 入 時 } \\
\text { 水頭勾配 } \\
T_{1}, T_{2} \text { 間 }\end{array}$ & 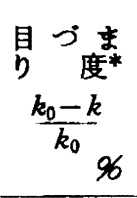 & $\begin{array}{l}\text { 再掦水時 } \\
\text { 水頭勾配 } \\
T_{1}, T_{2} \text { 間 }\end{array}$ & 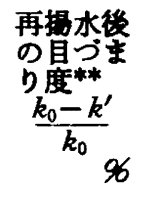 & $\begin{array}{l}x=2 \mathrm{~cm} \\
\text { の抑 留 } \\
\text { 量*** } \\
\text { (無次元毒) }\end{array}$ \\
\hline $1 \mathrm{~A}$ & 0.170 & 0.45 & $\cdots \cdots$ & 0.51 & 92.5 & $\cdots \cdots$ & ...... & 0.0436 \\
\hline B & 0.125 & 0.45 & ...... & 0.51 & 81.1 & 1.02 & 35.6 & 0.0259 \\
\hline $3 \mathrm{~A}$ & 0.151 & 0.43 & 800 & 0.51 & 55.0 & $\cdots \cdots$ & $\cdots \cdots$ & 0.0157 \\
\hline B & 0.144 & 0.43 & $\sim 1000$ & 0.51 & 51.2 & 1.03 & 33.4 & 0.0167 \\
\hline $4 \mathrm{~A}$ & 0.142 & 0.43 & 500 & 0.50 & 67.8 & $\cdots \cdots$ & $\cdots \cdots$ & 0.0173 \\
\hline B & 0.165 & 0.43 & $\sim 660$ & 0.50 & 65.5 & 1.03 & 53.8 & 0.0195 \\
\hline $6 \mathrm{~A}$ & 0.159 & 0.44 & 330 & 0.50 & 50.3 & $\ldots \ldots$ & $\ldots \ldots$ & 0.0174 \\
\hline B & 0.143 & 0.45 & $\sim 470$ & 0.50 & 48.3 & 1.03 & 30.0 & 0.0140 \\
\hline $7 \mathrm{~A}$ & 0.140 & 0.44 & 250 & 0.51 & 31.4 & $\ldots \ldots$ & $\cdots \cdots$ & 0.0145 \\
\hline B & 0.137 & 0.44 & $\sim 300$ & 0.51 & 29.9 & 1.03 & 25.4 & 0.0140 \\
\hline $8 \mathrm{~A}$ & 0.134 & 0.44 & 300 & 0.51 & 39.2 & $\ldots \ldots$. & $\ldots \ldots$ & 0.0157 \\
\hline B & 0.150 & 0.44 & $\sim 400$ & 0.51 & 42.0 & 2.02 & 22.0 & 0.0091 \\
\hline $10 \mathrm{~A}$ & 0.141 & 0.44 & 600 & 0.51 & 45.4 & $\cdots \cdots$ & $\ldots \ldots$ & 0.0305 \\
\hline B & 0.189 & 0.44 & $\sim 900$ & 0.51 & 85.2 & $\ldots \ldots$ & $\ldots \ldots$ & 0.0325 \\
\hline $11 \mathrm{~A}$ & 0.173 & 0.43 & 900 & 0.51 & 36.2 & $\ldots \ldots$ & $\ldots \ldots$ & 0.0214 \\
\hline B & 0.175 & 0.43 & $\sim 1000$ & 0.51 & 47.4 & 2.05 & 17.7 & 0.0127 \\
\hline $12 \mathrm{~A}$ & 0.166 & 0.44 & 700 & 0.51 & 38.8 & $\ldots \ldots$ & $\cdots \cdots$ & 0.0268 \\
\hline B & 0.204 & 0.45 & $\sim 800$ & 0.51 & 62.1 & 2.01 & 32.3 & 0.0165 \\
\hline
\end{tabular}

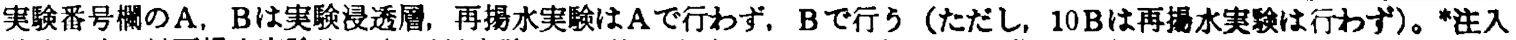

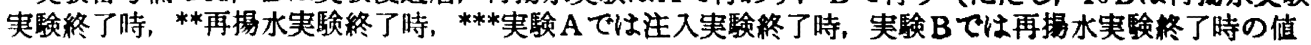




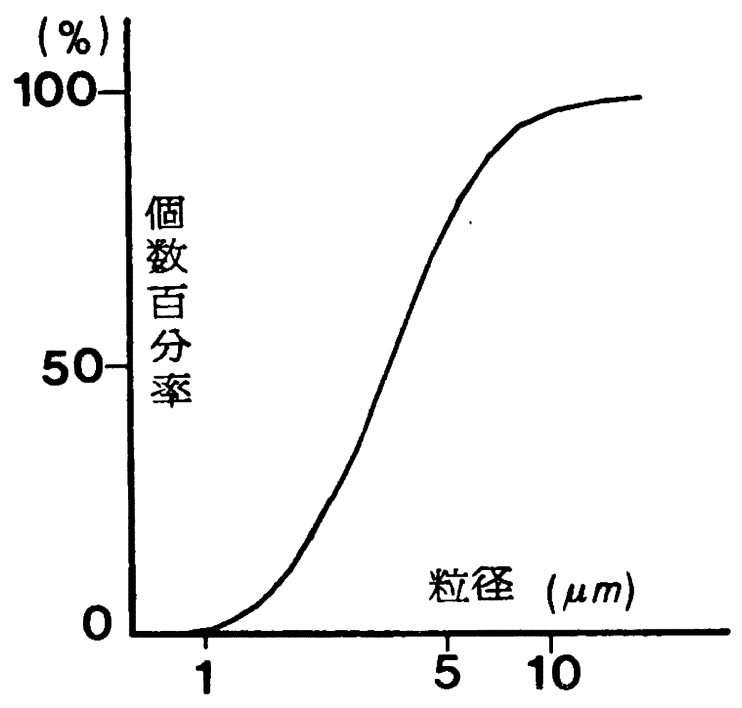

図-5 毇濁粒子の粒径分布

Fig. 5 Grain size distribution of clogging material
験では $T_{1}$ および $T_{2}$ の水位を一定値に保っている から，流量の減少は透水係数の低下によると言える。

2）透水係数の变化

照濁粒子の抑留とともに透水係数が場所的にも時 間的にも低下するが, 特に $T_{1}$ 側での低下が著しい。 図-7は時間とともに浸透䅉 $\mathrm{A}$ の透水保数の場所的分 布が変化する様子を示したものであり（実験 7 ）， 透水係数の低下が認められるのは $\mathrm{T}_{1}$ 側からせいぜ い $30 \mathrm{~cm}$ 程度となっている。

3）抑留量の場所的変化

図-8の白点は注入実験終了後，平均透水係数か; 初期平均透水係数のほほ $70 \%$ (実験 7 )，60\%（実験 8 )に低下した時点の $q_{s}$ の分布を示している。図-7 に対応して $T_{1}$ 側で著しい抑留がみられる。また， 黒点は浸透層 B での再揚水後の $g_{8}$ の分布を表して いる。浸透層 B の再揚水後の抑留量は, 再揚水前の 抑留量（再揚水を行わない浸透層 $\mathrm{A}$ の抑留量にほぼ

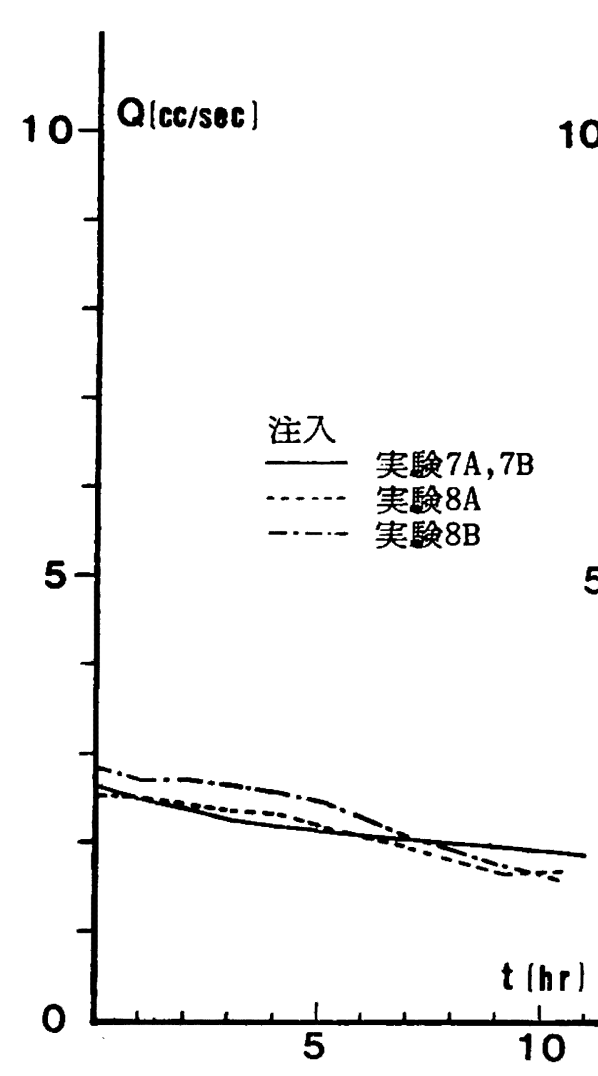

(a)

Fig. 6(a) Flow rate during recharge

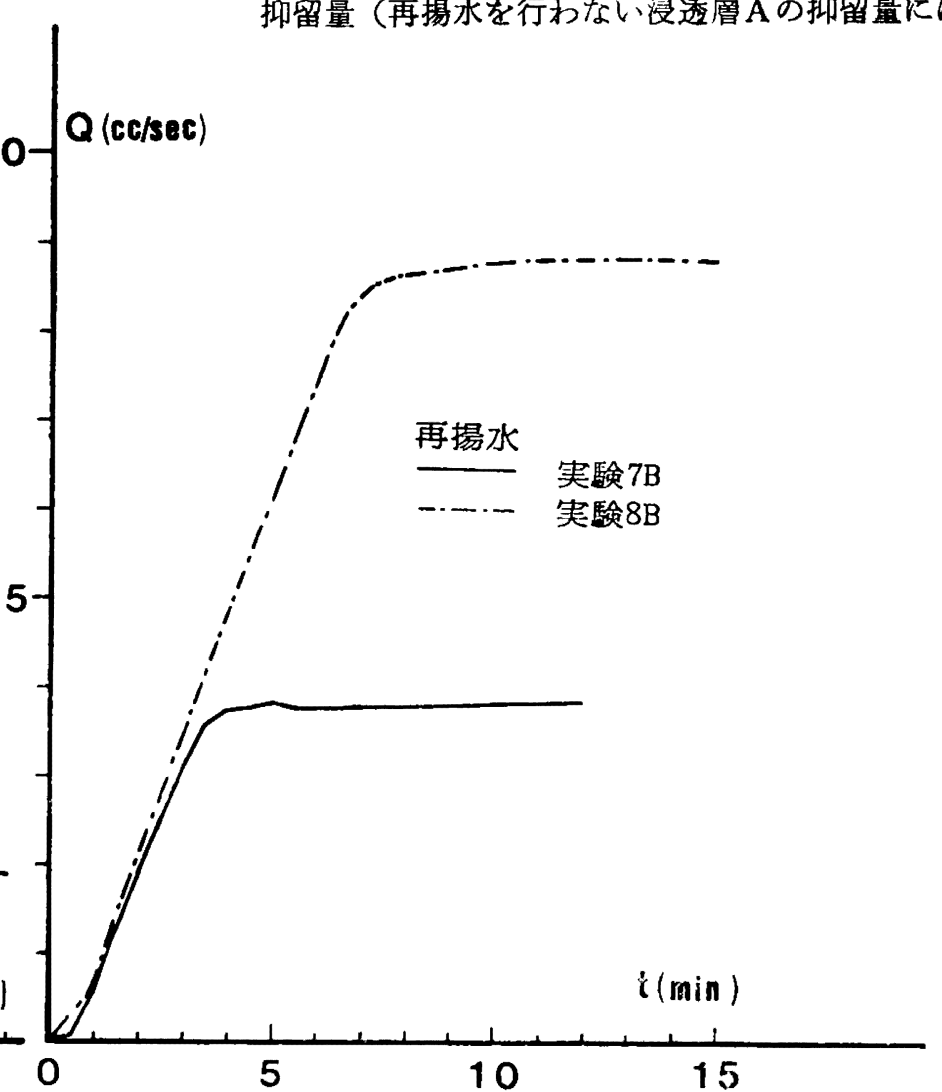

( b ) 


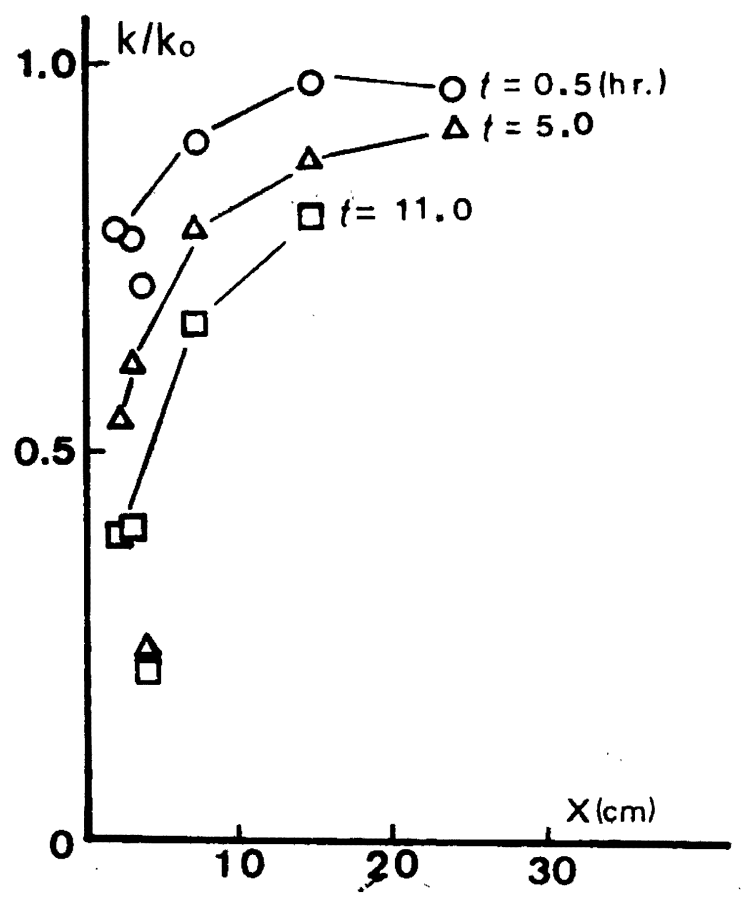

図一 7 注入時の透水係数分布の時間的变化（実験7）

Fig. 7 Change of permeability distribution with time during recharge (run 7)

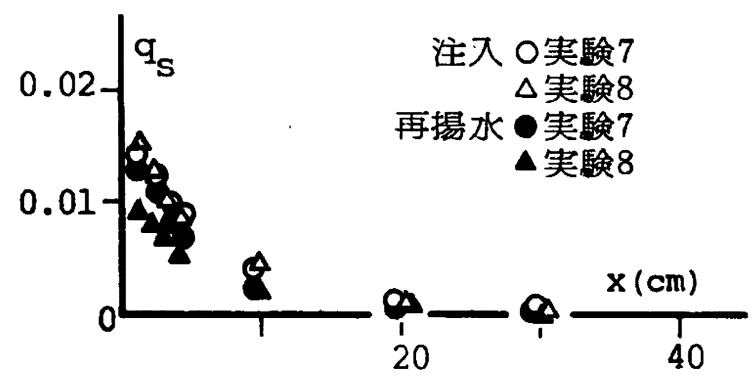

图-8 照罢粒子抑留目の分布

Fig. 8 Distribution of captured clogging material

等しいとしている) に比べて低下しており再揚水に よって抑留粒子が槑離したことが判る。また别離量 は，抑留量の多い $T_{1}$ 側で最も大きい。また，実験 8 では再揚水により抑留量がほぼ 3 分の 2 に減少し ているのに対し，実験 7 では大きな差異は認められ ない。これは，表-1に示すよらに実鈳 8 の再揚水時 の水頭勾配（ほほ2，0）であったのに対し，実験 7 の水頭勾配（ほぼ1，0）が小さく，せん断応力が寒 験 8 より小さかったためと考えられる。

4）再揚水洔の流量变化
: 再揚水時の流量を図-6 (b)に示している。時間 とともに流量が增加するが，これは再揚水 $\mathrm{T}_{1}$ の水 位上昇に，ある程度の時間がかかるため，それに応 じて生じた流量の增加分と水頭勾配の上昇に伴って 生じた砂粒子表面に働くせん断応力の增加により， 抑留粒子が剥離し，透水係数が回復することによる 流量增加分とに分けて考鼻ることが出来るが，両者 は同時に進行するのでこの図から区別するのは難し い。詳しい考察は後に述べる。

\section{5) せん断応力}

せん断応力ての算定はマノメータにより得られた 水頭勾配と流量の実測値から透水係数 $k$ を算出しを れを用いて式(17)から愁濁物質抑留量 $q_{s}$ を算定し, 次に, 式(7)より $r^{\prime}$ を求め, 式 (6)よりてが算定さ れる。な技，この計算に含まれるfoには図-11で得 られる $f_{\sigma}=0.90$ を用いた。浸透層 $\mathrm{B}$ の $\mathrm{T}_{1}$ 側から $2 \mathrm{~cm}$ のころでの注入時せん断応力の時間変化を 困-9に示している。時間の経過とともにせん断応力 が增加することがわかる。これは，抑留が進行し木 頭勾配が大きくなった結果と考えられる。

図-10は再揚水時のせん 断応力の実測値を示して いる。これによると, 再揚水開始後, 初期にはせん 断応力 てはほぼ直線的に增加するが，ある時点から

○寒駼 7

1 実臨8

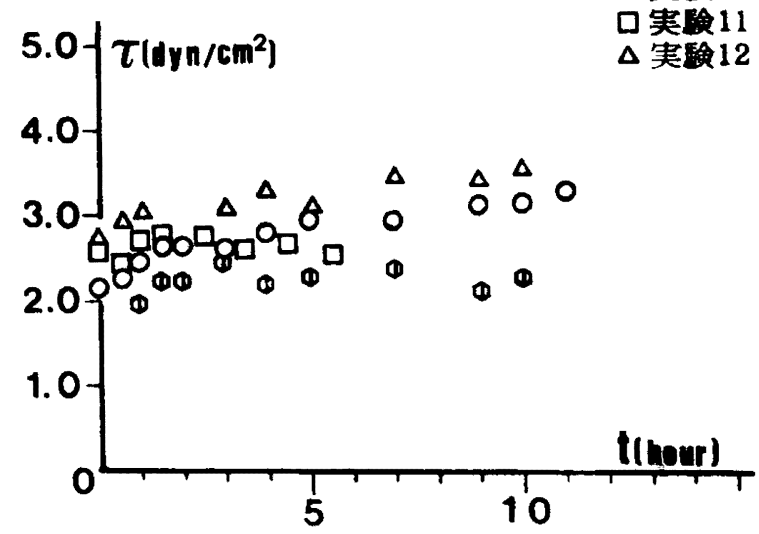

因-9 注入時のせん断応力の变化 $(x=2.0 \mathrm{~cm})$

Fig. 9 Change of shear stress with time during recharge $(x=2.0 \mathrm{~cm})$ 
急に増加が停止し，それから徐々に低下して一定值 に近づくよらである。

これは，再揚水開始にあたって $\mathrm{T}_{2}$ の水位の上昇 につれて浸透層全体の水頭勾配が大きくなるため, てが增加し, これがある值 (限界せん断応力 $\tau_{c}$ ) 以 上になると急激に剩離が生じ，ての增加は停止し， 次いで徐々に低下していきても一定となる。この 一定となったてが限界せん断応力汇と考えられ，各 実験により異なった值をとるようである。

2 物理定数についての考察

基礎式を用いて目づまり現象をシュミレートする ためには物理定数を决定する必要がある。前述のよ らにこれらを解析的に決めることは容易ではないの

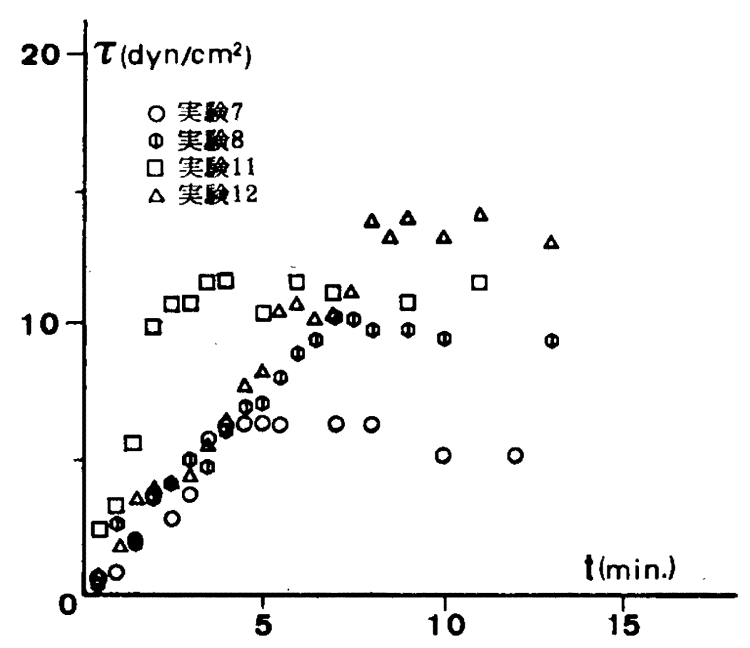

図-10 再揚水時のせん断応力の変化 $(\mathrm{x}=2.0 \mathrm{~cm})$

Fig: 10 Change of shear stress with time during back-pumping $(x=2.0 \mathrm{~cm})$
で、ここでは流量, 水頭勾配, 抑留量, などの実測 値などから求めることを考えよう。

1) 2 次空隙率 $f_{\sigma}$ の推定

実験修了時の浸透層の各断面に批ける透水保数之 抑留量の実测データを図-11に示している。なお, こ の実測値は図中に式(17)の算定曲線を併記する必要 上 $\varepsilon_{0}$ が同じ值 $\left(\varepsilon_{0}=0.44\right)$ を選んでいる。眓中の白点 は注入実験修了後の浸透周Aについて，また黒点は 再揚水実験修了後の浸透層 B についての結果である （ただし，実験10Bは再揚水を行っていないので白 点にしてある)。次に，図中には 3 種の $f_{a}$ を与文， $\varepsilon_{0}=0.44$ として Kozeny-Stein 式(17) により算定し た結果を実線で示している。これから， $f_{\sigma}=0.85 〜$ 0.95 , 平均的には0.90程度が実験值にほ注合ってい るようである。したがって，後述のシミュレーショ ンでは $f_{\sigma}=0.90$ を採用している。

2) 定数 $\beta_{1}$ の推定

$k / k_{0}$ の時間微分を

$$
\frac{\partial\left(k / k_{0}\right)}{\partial t}=\frac{\partial\left(k / k_{0}\right)}{\partial q_{s}} \cdot \frac{\partial q_{8}}{\partial t}
$$

の式形にする。いま，注入実験を考光，(4)式の右 辺第 2 項を除いた式について，抑留の初期の段階を 考えて， $q_{3} \sim 0 ， \varepsilon \sim \varepsilon_{0}$ とし，また浸透層の $\mathrm{T}_{1}$ 側に 近いところで $C \sim C_{i n}$ （注入濃度）と近似させ, 得 られた式(4)を式(22)へ代入すると

$$
\frac{\partial\left(k / k_{0}\right)}{\partial t}=\frac{\partial\left(k / k_{0}\right)}{\partial q_{s}} \varepsilon_{0} C_{i n} \frac{\beta_{1}}{\sigma_{s}\left(1-\varepsilon_{0}\right)}
$$

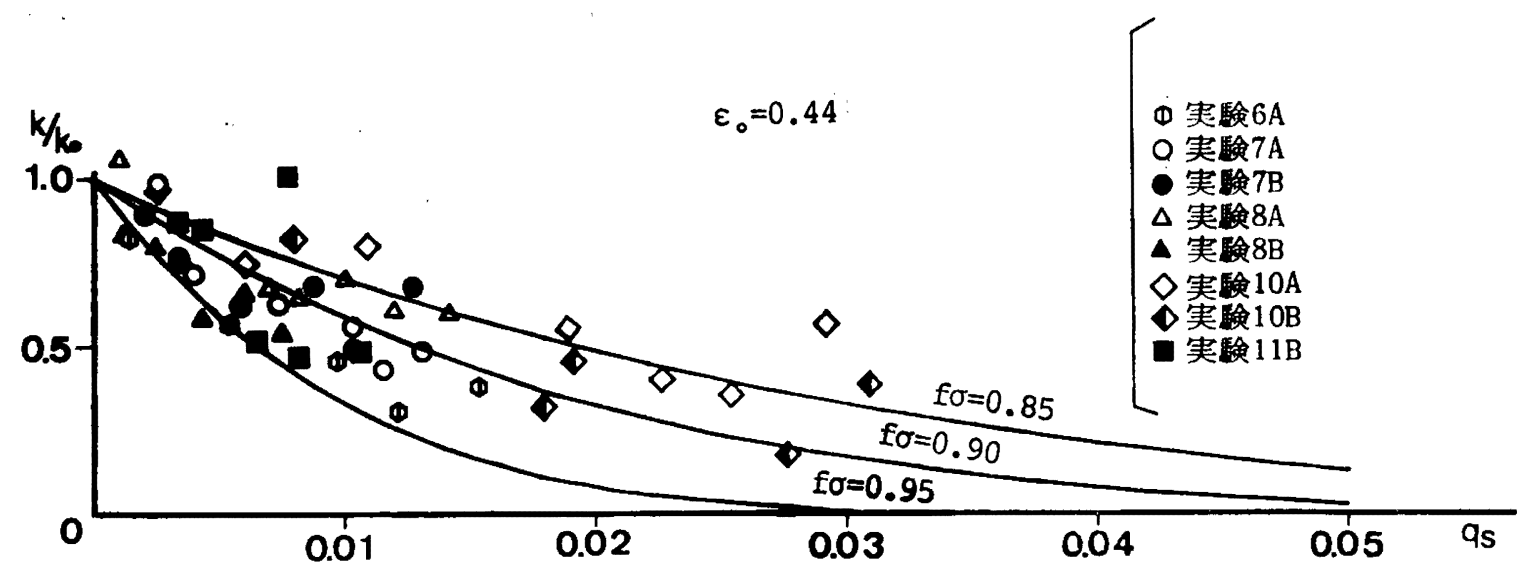

図-11 透水係数と紫罣粒子抑留量の関係 (Kozeny·Stein 式)

Fig. 11 Relationship between permeability and captured clogging material (Kozeny-Stein eq.) 
または

$$
\beta_{1}=\frac{\partial\left(k / k_{0}\right)}{\partial t} \quad \frac{\sigma_{s}\left(1-\varepsilon_{0}\right)}{\left\{\partial k / k_{0}\left(/ \partial q_{s}\right\} \varepsilon_{0} C_{i n}\right.}
$$

従って, 上式に注入初期， $\mathrm{T}_{1}$ 側注入口付近での $k / k_{0}$ の実測值の時間的変化を，また $\partial\left(k / k_{0}\right) / \partial q_{s}$ には 透水係数と㲘濁粒子抑留量の関係式である KozenyStein 式(18)で $q_{s} \sim 0$ 付近の值を適用すれば定数 $\beta_{1}$ を推定することが出来る。例として表-1より数例の 実験を選んで $\beta_{1}$ の值を算定してみよう。まず実験 結果より得られた $k / k_{0}$ と $q_{8}$ の関係は図-11に示さ れている。この四から $f_{\sigma}=0.90$ の曲線の $q_{s}=0$ 付 近の勾配 $\partial\left(k / k_{0}\right) / \partial q_{s}$ の値を読み取ると，ほぼ $\partial$ $\left(k / k_{0}\right) / \partial q_{\delta} \sim 50$ を得る。また， $T_{1}$ 側から $2 \mathrm{~cm} の$ ところでの実湘の透水係数の時間変化は図-12 に示 されるのでこれより $\partial\left(k / k_{0}\right) / \partial t$ の値を読み取る とほぼ1. $0 \times 10^{-4} \sim 1.0 \times 10^{-5} / \mathrm{sec}$ 程度となり，ここ では平均して $5.0 \times 10^{-5}$ を用いることにする。また， $\sigma_{s} ， \varepsilon_{0} ， C_{i n}$ にそれぞれの実験による值を代入し，式

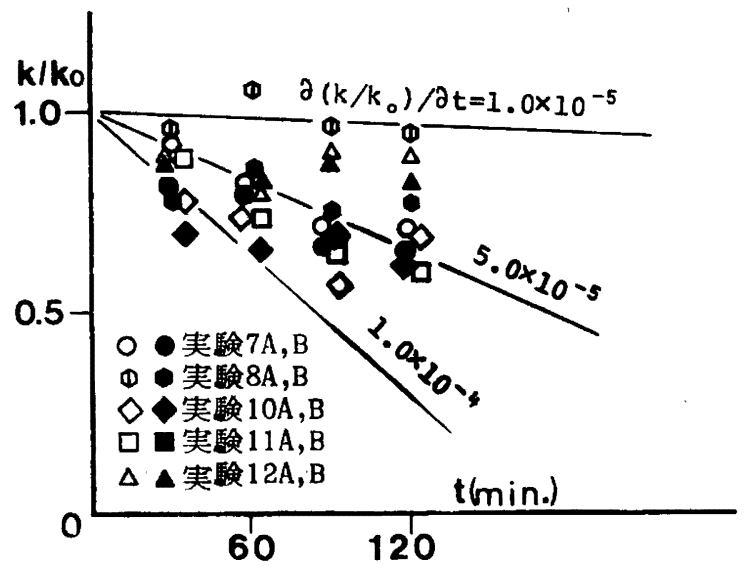

図-12 注入時の透水俰数の变化 $(\mathrm{x}=2.0 \mathrm{~cm})$

Fig. 12 Change of permeability with time during recharge $(x=2.0 \mathrm{~cm})$

表-2 定数 $\beta_{1}(1 / \mathrm{sec})$ の推定

Tab. 2 Estimation of coefficient $\beta_{1}$

\begin{tabular}{c|c|c}
\hline 実 & 験 1 第 1 近似值 & 最終推定值 \\
\hline $7 \mathrm{~B}$ & 0.025 & 0.002 \\
$8 \mathrm{~B}$ & 0.077 & 0.008 \\
$11 \mathrm{~A}$ & 0.005 & 0.005 \\
$11 \mathrm{~B}$ & 0.025 & 0.003 \\
$12 \mathrm{~B}$ & 0.007 & 0.007
\end{tabular}

（28）から $\beta_{1}$ を算定すると表-2の第 2 㯗のよらにな る。そこでこれらの（第 1 近似）を丸めた値を用い てシミェレーションを行い流量を計算する。この結 果を図-13(a)〜 (e) に示す。な拉，この図には実測 の丸印に合わせるように第 1 近似値の $\beta_{1} *$ のオーダ 一を変えて，同様のシミュレーションを行った結果 も示している。これから，実測の流量にほぼ合う $\beta_{1}$ を推定して，これを表-2の第 3 欗に示している。

また， 1 例として，実験11Aについて注入最終状 態の摠濁粒子抑留量 $q_{s}$ の実測値と上述のシミュレ ーションによる值を比較すると図-14のようになり， この実験では $\beta_{1}=0.005$ は抑留量の分布からもほぼ 妥当なものであるといえる。

3）定数 $\beta_{2}$ の推定

図-2にも示しているよらに, 式 (8) から $q_{s}=1 / \beta_{2}$ の とさ $\lambda=0$ となり，この時懸溞物質の抑留は停止す る。すなわち、このとき抑留は飽和に達したといえ る。従って㩓濁粒子の㧕留量 $q_{s}$ の飽和量は $1 / R_{2}$ と 考えられる。注入実験終了後に抑留量 $q_{s}$ を実測す ると表-1 の第 9 欗に示すように， $T_{1}$ 側に近いとこ ろ $(\mathrm{x}=2.0 \mathrm{~cm})$ で $q_{s}$ のほぼ最大值に近い值として 0.02〜0.05が得られた。このことから $q_{s}$ が0.05程 度の值を超えることはないと考えられる。従って本 報では $\beta_{2}$ として0.05の逆数，すなわち $\beta_{2}=20.0$ を大体の目安として与えることにする。また，前述 のように，今回の実験結果図-11 からほぼ妥当と考 えられる定数 $f_{\sigma}=0.90$ に対する Kozeny-Stein 式 の曲線からみると， $q_{s}=0.05$ で透水係数 $k / k_{0}$ が十 分小さくなっていることからも，qs の最大值は 0.05 となり， $\beta_{2}=20.0$ と推定できる。

\section{4) 定数 $B_{3}$ の推定}

$B_{3}$ は式 (4)の右辺第2 項に見られるように抑留さ れた想濁粒子の剥離の大きさに関する值である。 䧄は次のようにして推定できる。式 (4) 右辺第1 項 は慜濁粒子が抑留される項を表わしているが，再瑪 水実験では清净水をへッドタンク $\mathrm{T}_{2}$ から供給して 

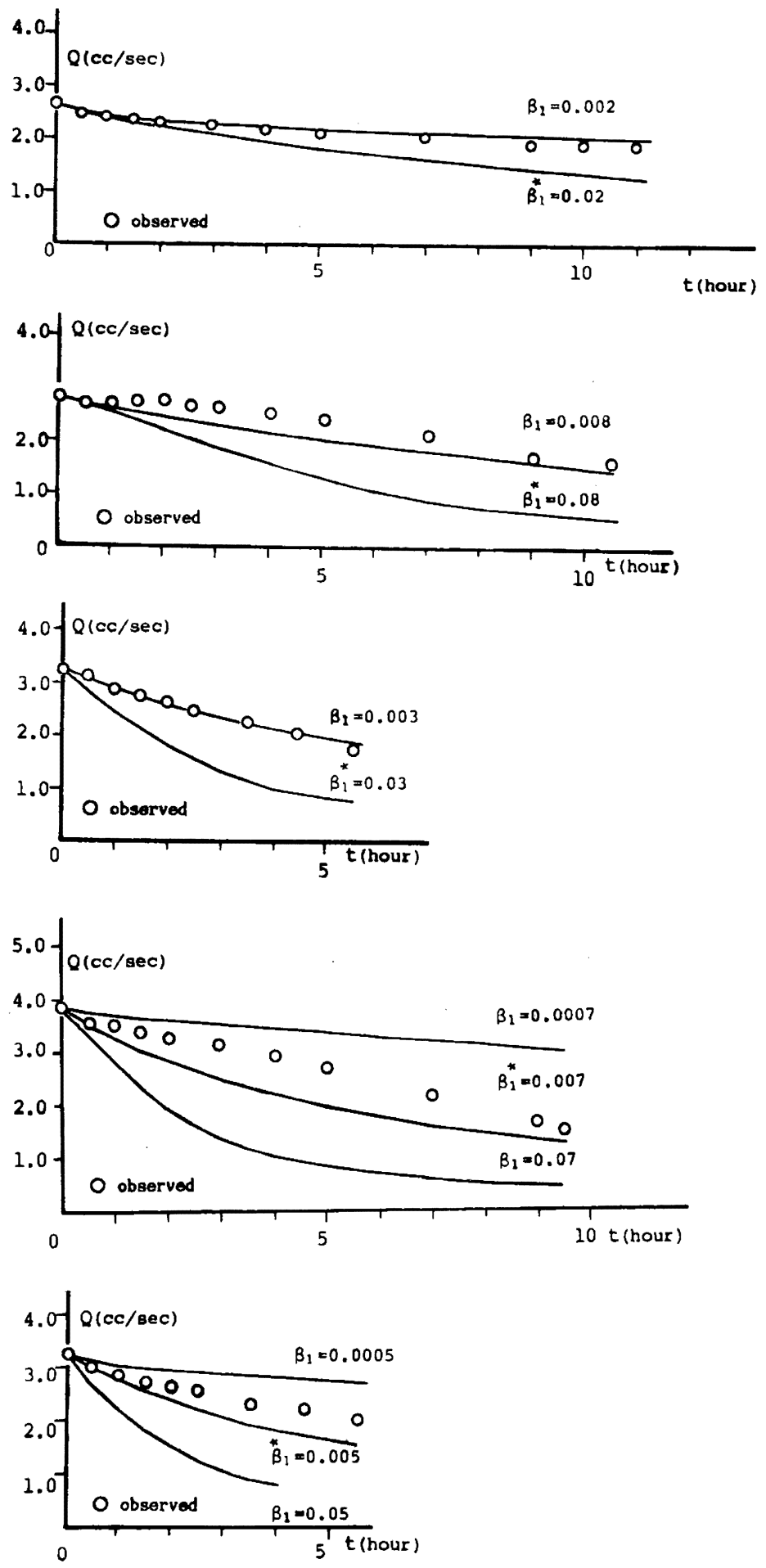

いるので，愁濁粒子の供給はない。したがって，間

吵水中の濁度として(1)注入実験終了時にろ材間隚に

取り残されたものと，(2)抑留されていた愁渴粒子が 世ん断応力によって制離し，間隙水中に再浮遊する ものとが考えられる。しかしながら，前者は再掦水 图-13(a) 注入流量の数值鼓（実験 7B）

Fig. 13(a) Numerical calculation 'of flow rate during recharge (run $7 \mathrm{~B}$ )

图-13(b) 注入流早の数值皁算（夷験 8B）

Fig. 13(b) Numerical calculation of flow rate during recharge (run $8 \mathrm{~B}$ )

图-13 (c) 注入流量の数值計算（垁歌11B）

Fig. 13(c) Numerical calculation of flow rate during recharge (run $11 \mathrm{~B}$ )

图-13(d) 注入流量の数值尌策（夷駼 12B）

Fig. 13(d) Numerical calculation of flow rate during recharge (rum 12B)

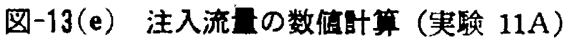

Fig. 13(e) Numerical calculation of flow rate during recharge(run 11A) 


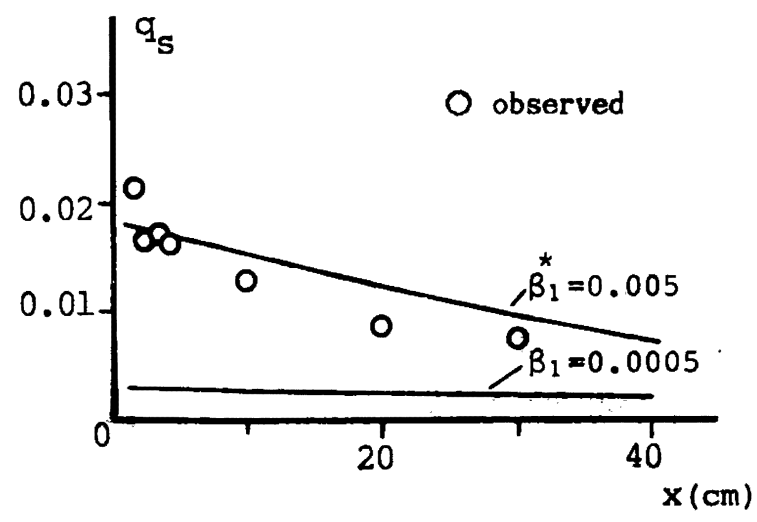

图-14想濁粒子抑留量分布の数値尌算（実驗 11A)

Fig. 14 Numerical calculation of captured clogging material (run 11 A)
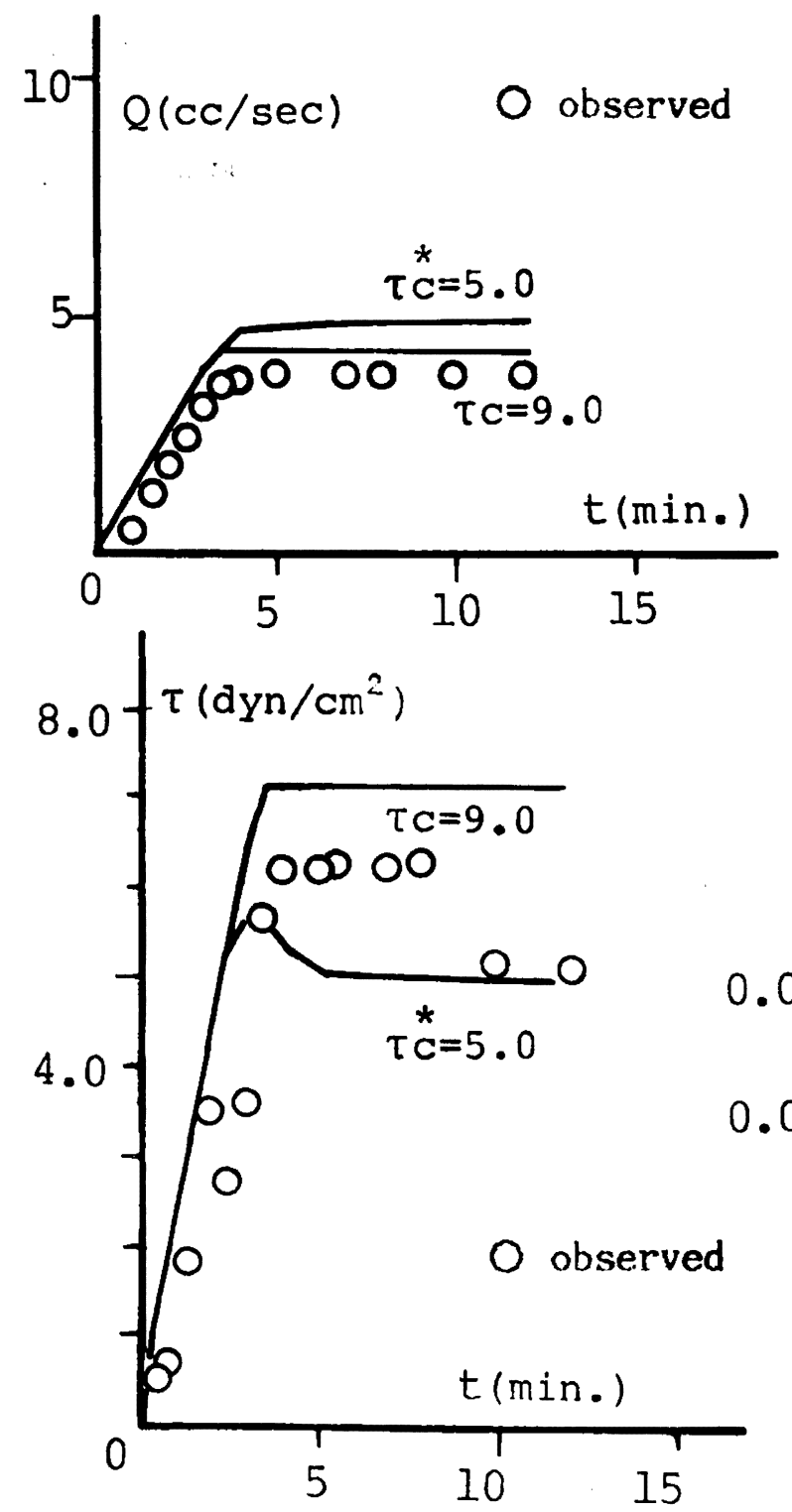

図-16（b）再掅水時のせん断応力（実駼 7)

Fig. 16(b) Shear stress during back-qumping(run 7)

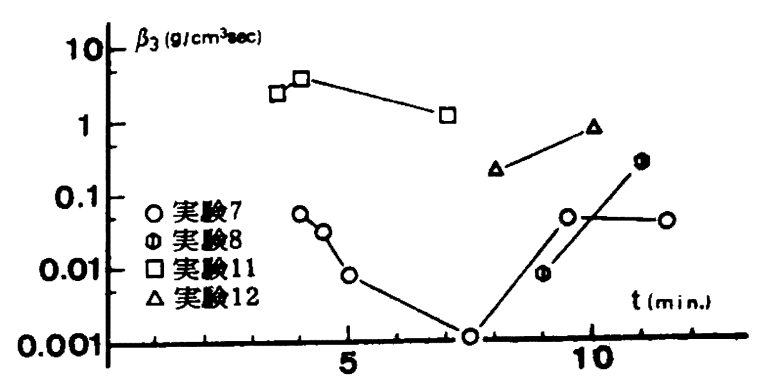

图-15 保数 $\beta_{3}$ の推定

Fig. 15 Estimation of coefficient $\beta_{3}$ 因-16（a）再揚水時の流是（実飺 7)

Fig. 16(a) Flow rate during back-pumping (run 7) 
表-3 限界せん断応力 $\tau_{c}\left(\mathrm{dyn} / \mathrm{cm}^{2}\right)$ の推定

Tab. 3 Estimation of critical shear stress $\tau c$

\begin{tabular}{|c|c|c|}
\hline 実 験 & $\begin{array}{c}\text { 第 1 近似値 } \\
\tau_{c}{ }^{*}\end{array}$ & 最終推定值 \\
\hline 7 & 5.0 & 9.0 \\
8 & 11.0 & 15.0 \\
11 & 9.5 & 9.5 \\
12 & 13.0 & 7.0 \\
\hline
\end{tabular}

のよ5に近似できる。これより $\beta_{3}$ は

$$
\beta_{3}=-\frac{\sigma_{8}\left(1-\varepsilon_{n}\right)}{\varepsilon f(\tau) q_{s}} \cdot \frac{\partial q_{s}}{\partial t}
$$

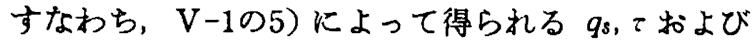
（11)からの もを与学れば，(26)から $\beta_{3}$ を算定でき る。この結果を困-15に示している。これによると，

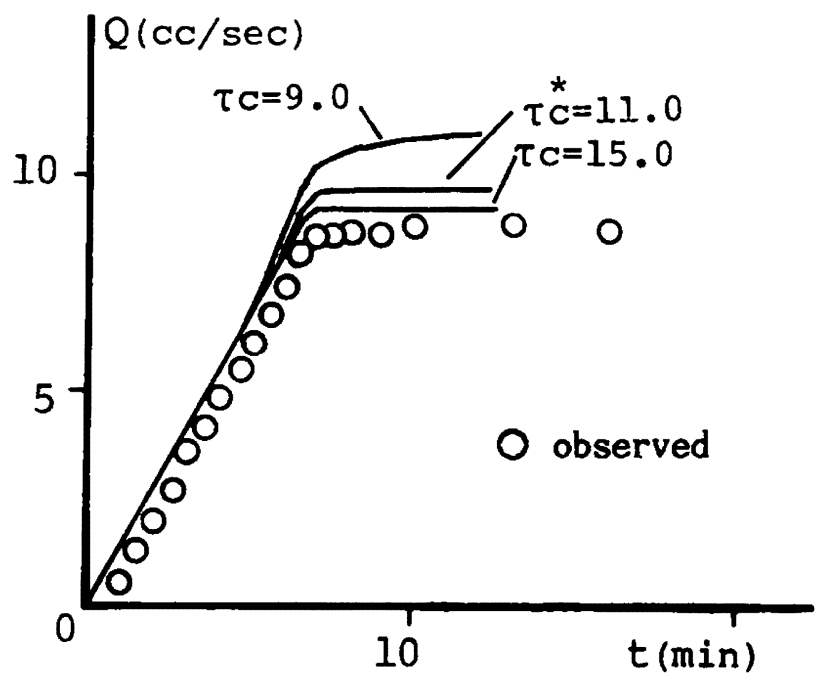

$B_{3}$ の值は $10^{-1}\left(\mathrm{~g} / \mathrm{cm}^{3} \cdot \mathrm{sec}\right)$ のオーダーと推定され る。, 多の値はかなり変えてもシミュレーション結果 にはあまり影響がなく、したがってシミュレーショ ンでは一応 $\beta_{3}=0.4\left(\mathrm{~g} / \mathrm{cm}^{3} \cdot \mathrm{sec}\right)$ を用いた。

5）限界せ之断応力 $\tau_{c}$ の推定

$\mathrm{V}$-195）で述べたように浸透層内で 発生するせ ん断応力が限界せん断応力以上になると，抑留され た愁濁粒子が除去され，最終的にはその場所のせん 断応力は限界せん断応力に等しくなるまで低下する ものと考号られる。従って再掦水時に打ける浸透層 の $T_{1}$ での出口付近の最終せん断応力を知ることに より限界せん断応力をほほ推定出来ると考えられ る。

いま図-10から限界せん断応力 $\tau_{c}$ の概略値として, 実験末期のてがほぼ一定值になったときの值を読み 取ると，表-3第 2 欗のよらになる。いまこれらの

\section{図-17（a）再揚水時の流量（実䍄 8)}

Fig. 17(a) Flow rate during back-pumping (run 8)

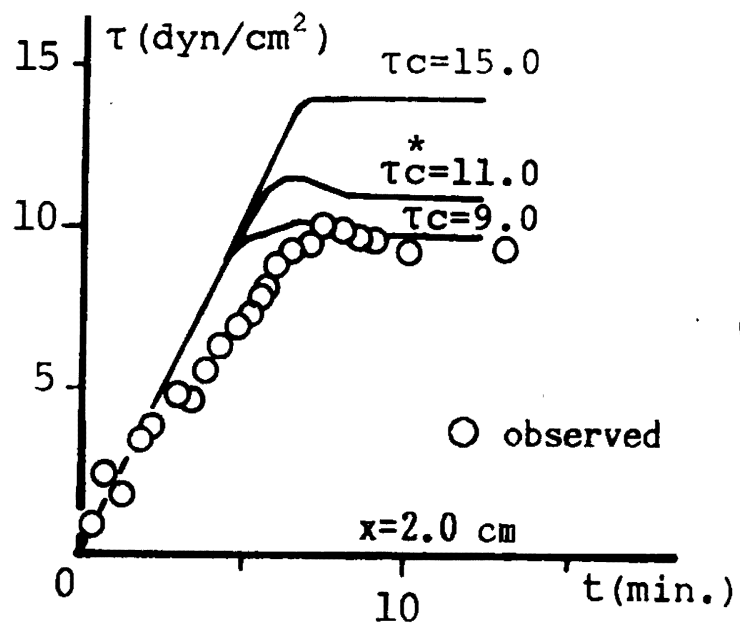

图-17（b）再揚水時のせん断応力（実験 8）

Fig.17(b) Shear stress during back-pumping(run 8)

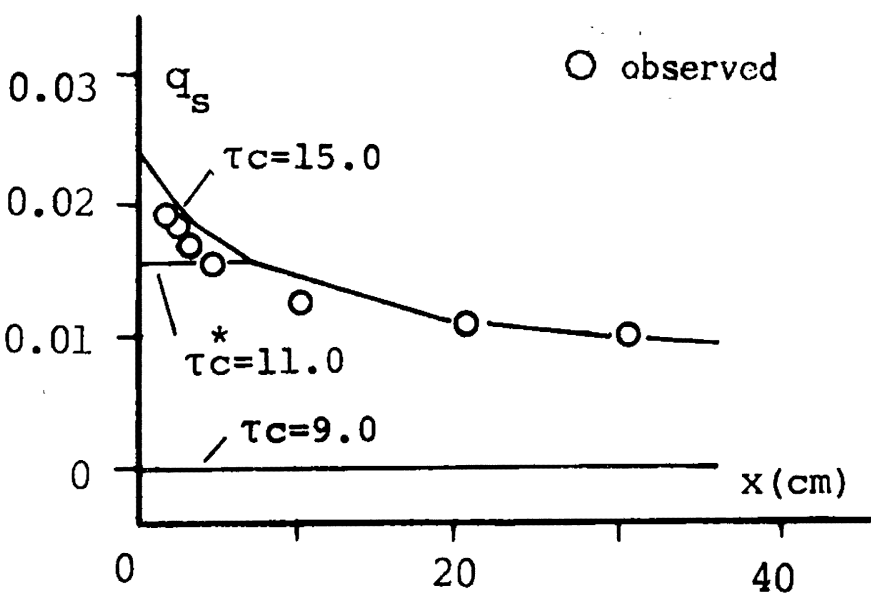

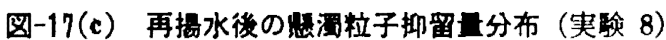

Fig. 17(c) Dstribution of captured clogging material afetr back-pumping (run 8) 


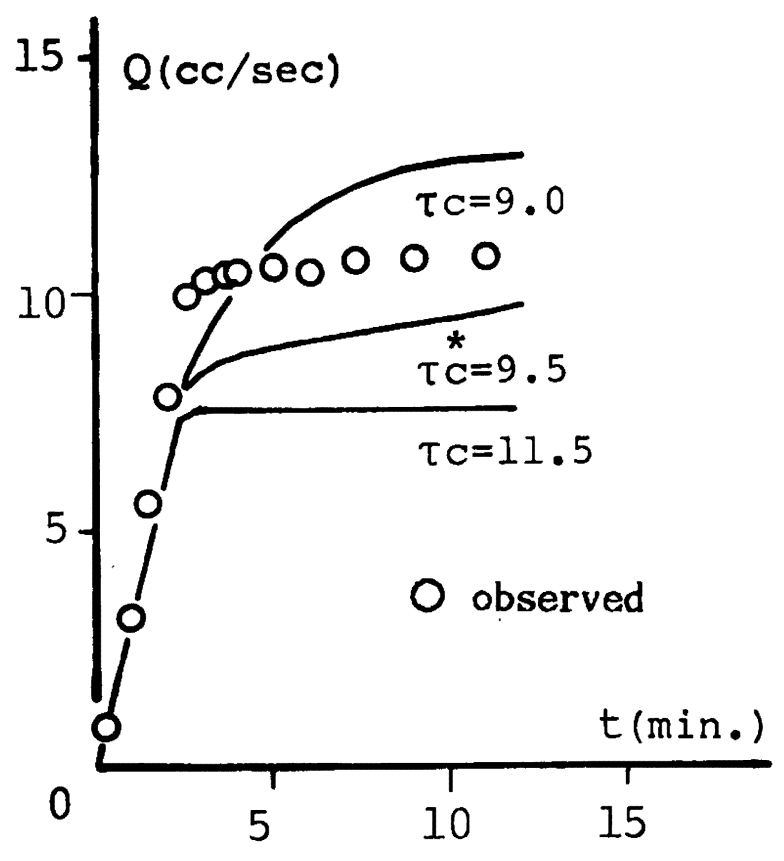

図-18（a）再搨水時の流量（実呀 11）

Fig. 18(a) Flow rate during back-pumping(run 11)

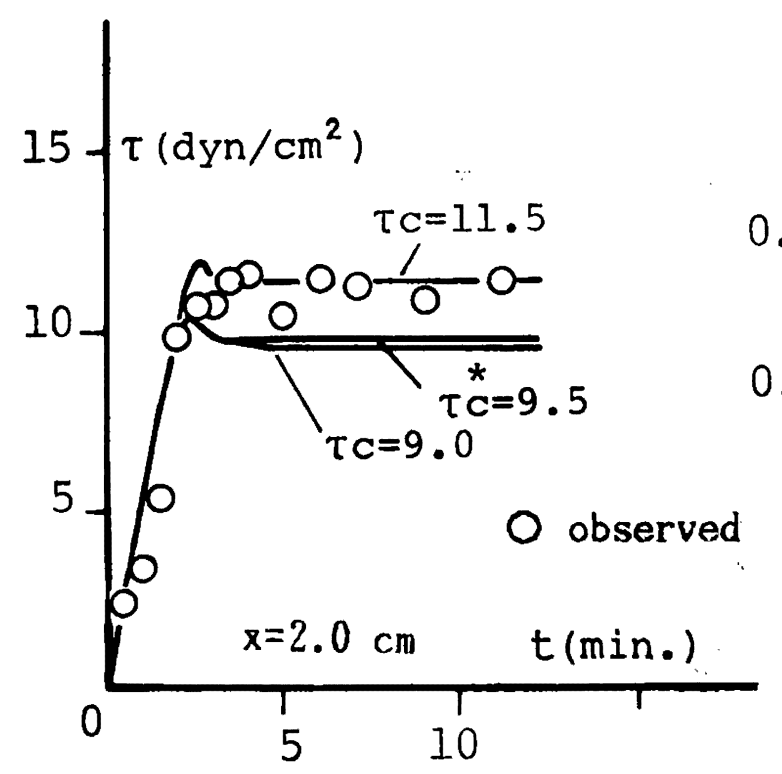

图-18（b）再搨水時のせん断応力（実験 11）

Fig.18(b) Shear stress during back-pumping(run 11) 值を $\tau_{c}$ の第 1 近似として, 再揚水実鈳のシミュレ ーションを行った。この結果得られた流量, せん断応 力，懸濁物質抑留量を図-16〜図-19の央線に示す。 つぎに，第 1 近似值の $\therefore$ * 以外の実線は，実測の丸 印の值に近似するように $\tau_{c}$ の值を変えた算定曲線 でありこれらの実線から丸印の点に合らようにて を推定したものが表-3の最終推定値である。なお， $\mathrm{B}$ 層で行った再揚水実験のシミュレーションの初期

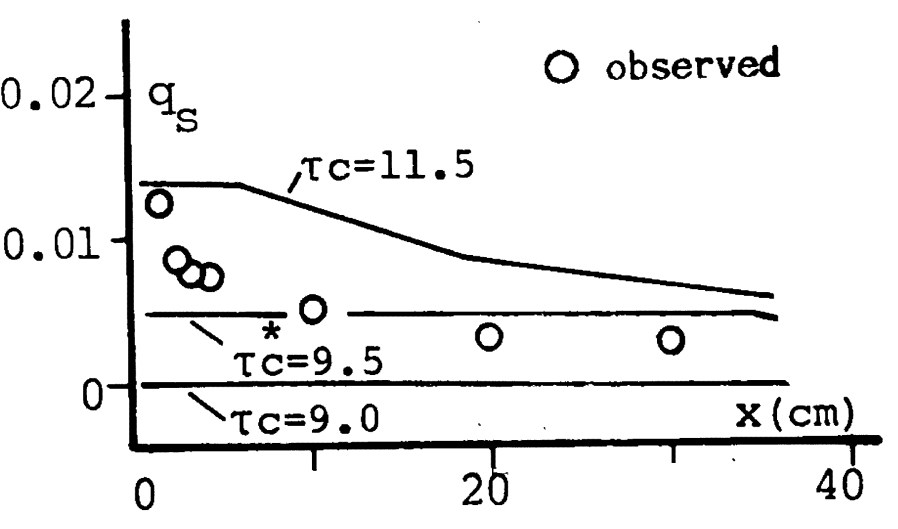

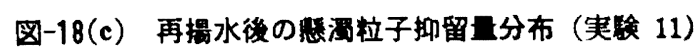

Fig. 18(c) Distribution of captured clogging material after back-pumping (run 11)

条件は，同じ実験のA層から得られた㗭濁粒子抑留 量の実測値を線形補間して得られた再樭水開始時点 での $q_{s}$ の分布, 扎よび, この $q_{s}$ の分布から Ko. zeny-Stein 式を用いて得られる透水係数の分布を初 期条件として与える。因-16〜図-19の qs の丸印は 再掦水実験終了後の実湘值，ての丸印は龱-10 と同 じである。

困-3をみると, 夷験 8 と来験 11 では第 1 近似值 


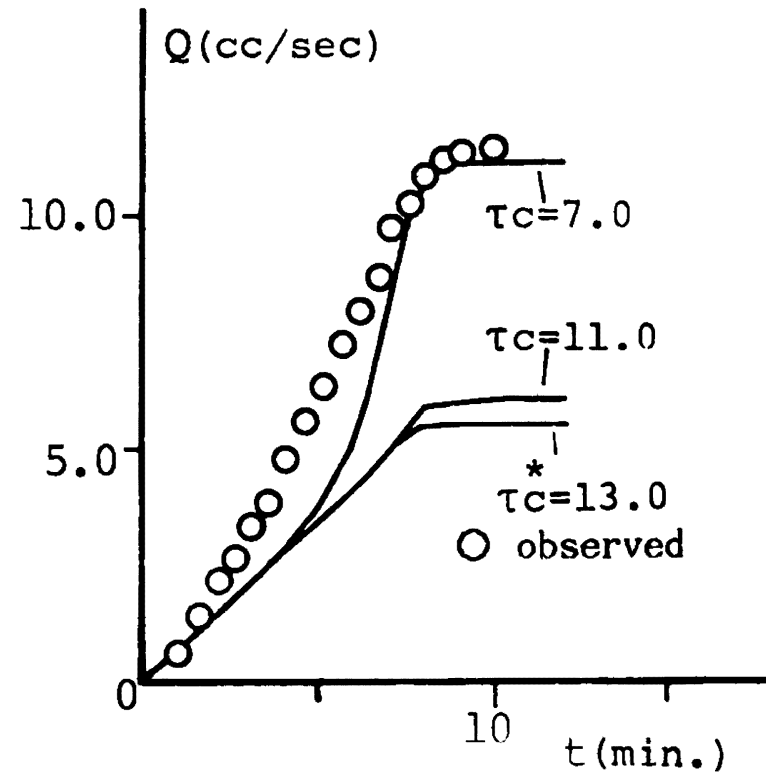

図-19（a）再掦水時の流望（実験 12）

Fig.19(a) Flow rate during back-pumping (run 12)

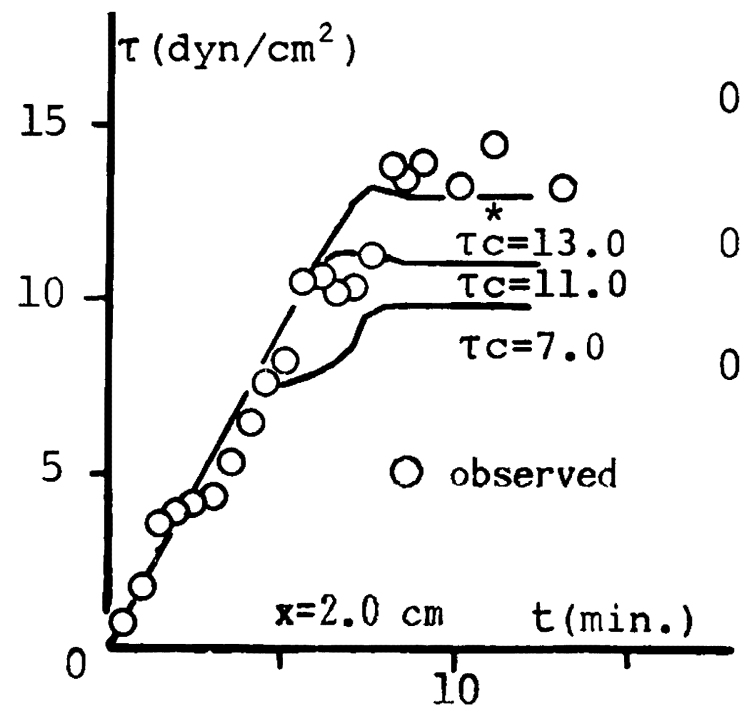

图-19（b）再揚水時のせん断応力（実険 12）

Fig.(b) Shear stress during back-pumping (run 12) と最終推定値とは忹近似していて，この方法で十 分現象を説明できるといえる。なお，実験 7 および 実験12で限界せん断忍力の第 1 近似値とシミュレー ション結果から得られた最終推定値かかなり遣って いる。この理由は明確ではないが, 実験 7 について は表-1および図-8からわかるように再揚水による照 濁物質の除去量が非常に少ない。これは，水頭勾配 が1.03と小さいためと考えられる。したがって， 汹ー10すなわち威-16(b)の丸印から読み取っだ $\tau_{c}$ (呀)

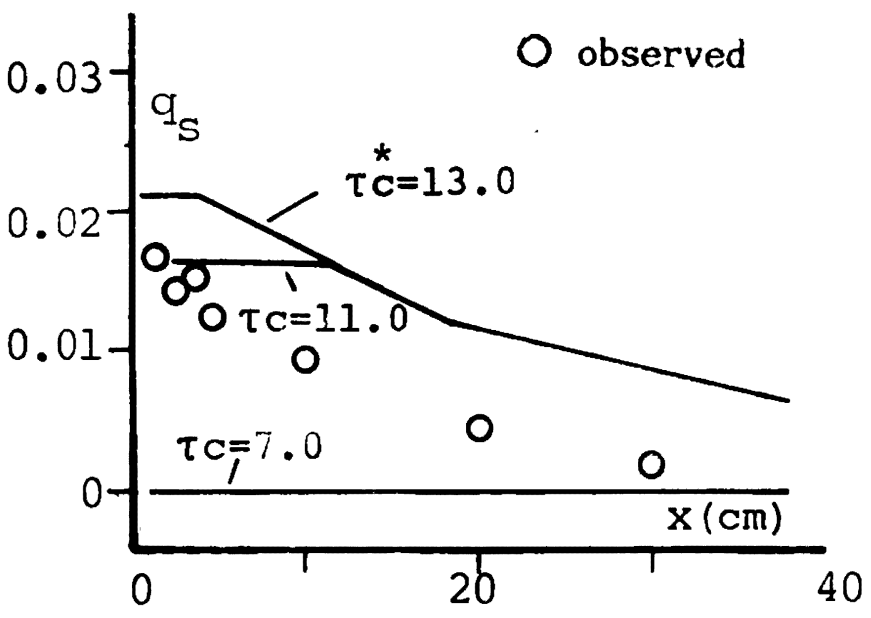

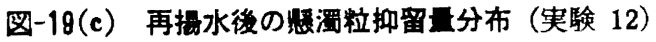

Fig. 19(c) Distribution of captured clogging material after hack-pumping (run 12)

1 近似値）は正確な限界せん断応力を示していない のではないかと考えられ，再掦水時の水頭勾配が小 さい場合には，ての決定には注意が必要と考えられ る。次に，実験12については，表-1に示すように注 入実験終了時の $\mathrm{A}$ 層と $\mathrm{B}$ 風の目づまり状態が大きく 異なっていることから教えると，この時点のA層と $\mathrm{B}$ 層の $q_{s}$ が異なり，したがって，B層の再揚水に関す るシミュレーションの初期条件にA層から得られた $q_{s}$ の分布を与えたことが不適切であったためと考 


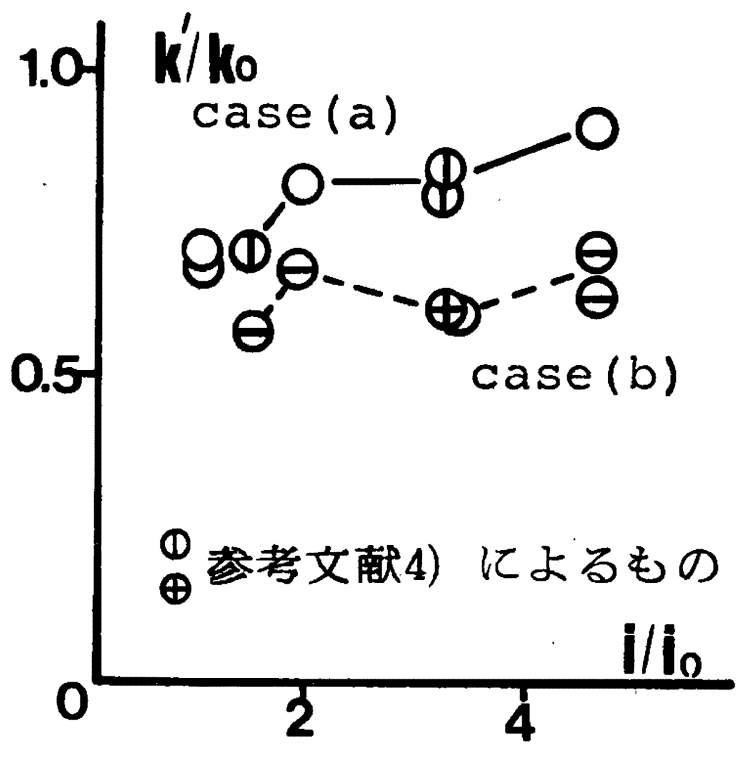

図-20再揚水時の水頭勾配 $\left(i / i_{0}\right)$ と目づまり度 $\left(k_{0}-k\right) / k_{0}$ が再揚水の奻果 $\left(k^{\prime} / k_{0}\right)$ に及ぼす影

불 (目づまり度 : case(a) 50\%, case(b) 60\%)

Fig. 20 Influence of hydraulic $\operatorname{gradient}\left(i / i_{0}\right)$ and degree of clogging $\left(k_{0}-k\right) / k_{0}$ on effect of back-pumping $\left(k^{\prime} / k_{0}\right) \quad$ [degree of clogging: case (a) 50\%, case(b)60\%]

えられる。

3 再揚水の効果

人工涵養注入井の目づまりに対する再揚水の効果 について，現地実験等から次のよらなことかいかれ ている6)。

a）再揚水は総揚水量よりも揚水率（単位時間あ たりの揚水量）を大きくして行った方が効果が大き w。

b）再掦水時の水頭勾配が注入時の水頭勾配より 高いほど効果が大きい。

c）目づまりの進行程度が低いらちに再揚水を行 った方が效果が大きい。

これらの事項を本報に物ける実験結果について考 察する。まず，目づまり度にはN-2で定義した値を 用いる。また，これと同じ記号を用いて再掦水の効 果には $k^{\prime} / k_{0}$ を用いる。次に，注入実験開始時の浸 透層全体の平均水頭勾配を $i_{0}$, 再揚水実験最終時の 浸透層全体の平均水頭勾配を $i$ とし，再掦水終了時
の水頭勾配として $i_{0} て ゙$ 除した $i / i_{0}$ を考えることに する。

図-20は，数例の実験結果について，目つるり度 $\left(k_{0}-k\right) / k_{0}[\operatorname{case}(\mathrm{a})$ は目つまり度 $50 \%, \operatorname{case}(\mathrm{b})$ は目 つまり度 $60 \%$ 」および再揚水時の水頭勾配 $i / i$, が再 揚水㚵果 $k / k_{0}$ にどのよ5に影響するかを示してい る。なお，この図には参考文献4)による実験結果も 含まれている。図は再揚水の効果が再揚水時の水頭 勾配の增大に応して增加することを表わしている。

これについて考光ると，本報では，再揚水奻果は 浸透層内の間隙に作用するせん断応力が大きいとし ている。せん断応力は水頭勾配に比例するので, 水 頭勾配が高いはど再揚水の効果は大きい。このこと から，再揚水は総揚水量を大きくじて行らよりも，

揚水率を大さくして行ったほらが効果が大きいとい らことが理解される。これから，前述の a)，b）が 肯定される。

次に，図-20から同一の水頭勾配に対しては目づ まり度の低い case(a) の方が case(b) よりる再揚 水の效果が大きい。これについて考えると，注入時 に浸透層間隙で生じるせん断応力は図-9のように時 間とともに，すなわち目つまりの進行ととすに濑次 増加するので，目づまり度が高いはどせん断応力は 大さい。したがって，図-20の case (b)は case(a) により大きいせん断応力のるとで抑留が生じていた と考兄られる。次に，抑留彩渴粒子のろ材からの制 離には注入時を上回るせん断応力が必要と考えられ る。そのため, $\operatorname{case}(\mathrm{b})$ は case(a) に比べて, 同 一の水頭勾配では抑留䅗濁粒子の豩離が小さく，再 揚水の効果は少ない。したがって，再揚水は，目づ まり度が低いらちに行ったほらが効果が大きいとい らことが理解できよう。これから前述のc）が肯定 される。

\section{V むすひ}

本報では，一次元浸透周モデルによる実鍳および 
シミュレーションを行い以下のよらな結果を得た。

1）地下水人工涵養時に生じる目づまり現象はろ 過方程式を用いてシミュレートすることができる。

2）透水係数と懸濁粒子抑留 量の関係式として Kozeny-Stein 式を適用できる。

3）透水係数の回復は浸透凮間隙に生じるせん断 応力が，抑留眯濁粒子を剥離させることによって生 ビる。

4）再揚水の効果は，同一の目づまり度に対して は，再揚水時の水頭勾配が高いほど大きい。また， 再揚水時の水頭勾配が同一であれば，目づまり度が 低いほど大きい。

5）基礎式中の定数を実験結果から推定すること ができる。(1) $\beta_{1}$; 浸透層注入口付近での透水係数 の時間的变化，および透水係数と䀣濁粒子抑留量と の関係を基に推定することができる。(2) $\beta_{2}$; 䋰濁 粒子の最大抑留量から求められる。(3) $B_{3}$; 再揚水 時の透水係数の变化を Kozeny-Stein 式で懸濁粒子 抑留量の変化に㯰きかえこれをもとに推定すること ができる。

(4) $f_{\sigma}$ : 実験終了時の透水係数と眯濁粒子抑留量か
ら得られる。(5) $\tau_{c}$ ；再掦水実験最終状態の浸透層 注入口でのせん断応力から知ることができる。

\section{萦考文献}

1）村下敏夫; 地下水人工涵盖の現状と将来, 第 1 回水資 源に関するシンポジゥム前刷集, pp. 532〜 537, 1977

2) Rebhun. M, Schwarz. J ; Clogging and Contamination Process in Recharge Wells, Water Resources Research, Vol. 4, no. 6, pp.1207 1217, 1968

3）北川 明，石崎勝義; 浮避物による目ゔりに関する 研究，第24回水理講演会論文集，pp. 91 96, 1980

4）安田 裕, 神野健二, 上田年比古; 人工涵致井戸の目 うまりに対する再揚水の勍果について，上木学会年次满 演会請演概要集，pp. 386〜387, 1981

5）丹保恝仁，小笠原緒一; 仯万過の抑留機序に関与る研 究(1)，水道協会雑誌，第458号，pp. 2 9, 1964

6）建設省土木研究所; 注入井による地下水の人工涵金, 土木研究所資料1493号, 1979

7) Ives. $\mathrm{K}, \mathrm{J}$; The Science Basis of Filtration, N. A.T.O., Advanced Study Institutes Series, pp. 203 241, 1975

8）神野健二; 浸透層内の緒方向分散保数および細管モデ ルについて, 地下水学会誌，等21巻，第 2 号，pp. 55 71, 1979

9) Camp. T, R; Theory of Water Filtration, A.S. C.E, sa 4, Vol. 90, pp. 1 30, 1964

10）神野健二, 上田年比古；粒子の移轵に上る移流分散方 程式の数值解法の㭘討, 士木学会論文報告集, 第 271 号, pp. $45 \sim 53,1978$

（受付：1983年 3 月 28 日，受理：1983年 7 月 30 日） 